\title{
A strategy to optimize the peptide-based inhibitors against different mutants of the spike protein of SARS-CoV-2
}

\author{
Prerna Priya $^{1 *}$, Abdul Basit ${ }^{2}$, Pradipta Bandyopadhyay $^{2}$ \\ 1. Department of Botany, Purnea Mahila College, Purnia, Bihar, India \\ 2. School of Computational and Integrative Sciences, Jawaharlal Nehru University, New \\ Delhi, India \\ *Corresponding author: priya.prerna54@gmail.com
}

Keywords: Molecular dynamics simulation, binding free energy, MM-PBSA, SARS-CoV-2, spike protein, mutation

\begin{abstract}
:
SARS-CoV-2 virus has caused high-priority health concerns at a global level. Vaccines have stalled the proliferation of viruses to some extent. Yet, the emergence of newer, potentially more infectious, and dangerous mutants such as delta and omicron are among the major challenges in finding a more permanent solution for this pandemic. The effectiveness of antivirals Molnupiravir and Paxlovid, authorized for emergency use by the FDA, are yet to be assessed at larger populations. Patients with a high risk of disease progression or hospitalization have received treatment with a combination of antibodies (antibody-cocktail). Most of the mutations leading to the new lineage of SARS-CoV-2 are found in the spike protein of this virus that plays a key role in facilitating host entry. The current study has investigated how to modify a promising peptidebased inhibitor of spike protein, LCB3, against common mutations in the target protein so that it retains its efficacy against the spike protein. LCB3 being a prototype for protein-based inhibitors is an ideal testing system to learn about protein-based inhibitors. Two common mutations N501Y
\end{abstract}


and $\mathrm{K} 417 \mathrm{~N}$ are considered in this work. Using a structure-based approach that considers free energy decomposition of residues, distance, and the interactions between amino acids, we propose the substitutions of amino acid residues of LCB3 inhibitors. Our binding free energy calculations suggest a possible improvement in the binding affinity of existing inhibitor LCB3 to the mutant forms of the S-protein using simple substitutions at specific positions of the inhibitor. This approach, being general, can be used in different inhibitors and other mutations and help in fighting against SARS-CoV-2.

\section{Introduction:}

SARS-CoV-2 is a novel, positive-sense, single-stranded RNA virus, belonging to the family Coronaviridae that emerged at the tail end of $2019^{1}$. It primarily affects the respiratory system ranging from mild to severe infection ${ }^{2}$. This virus is highly infectious and can easily transmit from one person to another ${ }^{3}$. This is responsible for the sudden outbreak of a pandemic that collapsed the global health care system and economy. At least 43 crores of people have been infected with SARS-CoV-2 and among them, more than 59 lakhs died (https://covid19.who.int/, data as of Feb 25, 2022). This crisis prompted scientists, doctors, manufacturers, and regulating authorities to race against time and develop treatments as well as vaccines.

SARS-CoV-2 consists of $\sim 30 \mathrm{~kb}$ nucleotides which encode approximately 29 proteins including four structural proteins (spike, membrane, envelope and nucleoprotein) ${ }^{4-5}$. The potential therapeutic targets of this virus include spike $(S)$, envelope $(E)$, membrane $(M)$, nucleoprotein (N), replicase polyprotein (chymotrypsin-like protease (3CLpro), or main protease (Mpro), papain-like protease (PLpro), RNA dependent RNA polymerase (RdRp), and other non-structural 
proteins) and transmembrane serine protease 2 (TMPRSS2) ${ }^{6-7}$. Strategies used to develop inhibitors against these potential therapeutic targets include i) drug repurposing ${ }^{8}$ either by experiment-based high throughput screening or structure-based virtual screening, ii) fragmentbased drug designing ${ }^{9}$, or iii) de novo drug design ${ }^{10}$. Spike protein and TMPRSS2 play a crucial role in the entry of viruses therefore the therapeutics designed against this protein can prevent the viral entry. Several peptide-based inhibitors were designed and tested against the S-protein of SARS-CoV-2 ${ }^{11-12}$. Hydrophilic compound, 'Salvianolic acid C' obtained from traditional Chinese medicine potently inhibits the membrane fusion of S-protein ${ }^{13}$. Antiviral 'arbidol' inhibits the trimerization of S-protein, however, no significant benefit of this molecule was observed in the clinical trial ${ }^{14-17}$. Novel drug-like compounds DRI-C23041 and DRI-C91005 inhibited the interaction of hACE-2 with S-protein in cell-free ELISA assay ${ }^{18}$. Chen et al. discovered six inhibitors against S-protein (Cepharanthine, abemacicilib, osimertinib, trimipramine, colforsin, and ingenol) that were tested against pseudotyped particles SARS-S and MERS-S ${ }^{19}$. MM3122, camostat mesylate, nafamostat, MNP10 (marine natural product 10) are some of the potential inhibitors of TMPRSS2 ${ }^{20-27}$. The E- protein of SARS-CoV-2 consists of 75 residues that form a homopentameric cation channel and are involved in the viral assembly, budding formation of the envelope and pathogenesis ${ }^{28-29}$. Amantadine, Rimantadine, Hexamethylene amiloride (HMA) and several flavonoids act as potent inhibitors against E-protein ${ }^{28,30}$. Several known inhibitors (e.g. nelfinavir, lopinavir, ritonavir) have been tested and show high binding affinity against the 3CLpro or Mpro that play a crucial role in the proteolytic processing of replicase polyprotein ${ }^{31-34}$. Being involved in the replication and transcription of the SARS-CoV-2 genome, RdRp is a potential drug target for SARS-CoV-2 ${ }^{35}$. Nucleotide analog Remdisivir and favipiravir bind efficiently with $\operatorname{RdRp}^{36-38}$. PLpro is a proteolytic enzyme and also affects the host antiviral immune response that 
leads to the viral spread ${ }^{39-40}$. GRL0617 is a promising inhibitor against PLpro ${ }^{41}$. Emergency use authorization has been given to several vaccines, monoclonal antibodies as well as antiviral drugs developed by various pharmaceutical companies to save lives during the pandemic ${ }^{42-45}$. As a result, more than 10 billion doses of vaccine have been already administered to curb the progress of COVID-19 (https://covid19.who.int/). Remdesivir, an antiviral drug, was used widely but did not show significant clinical benefit against COVID-19 ${ }^{46}$. Monoclonal antibodies 'sotrovimab' as well as the antibody cocktail - a combination of 'casirivimab' and 'imdevimab' have shown clinical benefits and reduced the hospitalization rate in patients with COVID-19 (https://www.covid19treatmentguidelines.nih.gov/) ${ }^{45,47-48}$. However, none of these has offered a real cure against this disease yet. People are also getting infected, post-vaccination, with new variants though showing milder infection ${ }^{49}$. Recently, FDA authorized two COVID-19 antiviral pills: 'Molnupiravir' (Merck, USA) and, 'Paxlovid' (Pfizer, USA) for emergency use in patients who are at high risk ${ }^{50-52}$. Though these pills worked well in clinical trials, the real-world efficacies of these pills are yet to be assessed.

One of the major challenges of treating COVID-19 is the appearance of different mutant strains of the virus. The mutation frequency of SARS-CoV-2 to form newer strains such as alpha, beta, a more aggressive delta, and the most recent omicron, is a major challenge in developing a treatment for COVID ${ }^{53-56}$. It also includes the question, of whether the treatments developed for SARS-CoV2 will work on its existing and upcoming variants ${ }^{57-59}$. The majority of the mutations reported are in the spike (S) glycoprotein, which is responsible for the entry of the virus inside the human host via human receptor protein Angiotensin Converting Enzyme-2 (ACE-2) ${ }^{60-62}$. In this work, we want to check if existing inhibitors can be modified in such a way that these retain their efficacy for the mutant forms. For a proof-of-principle study, we have taken a designed mini-protein inhibitor, 
LCB3, a prototype for protein-based inhibitors including antibodies ${ }^{12}$ (Figure 1). LCB3 is a 64 amino-acid-long, stable, potent miniprotein inhibitor that competes with ACE-2 and binds tighter with the S-protein ${ }^{12}$. It has the potential to be used as a therapeutic and may open options for direct delivery to the nasal passage or other parts of the respiratory system. However, several studies have shown mutations induced alteration in the binding affinity of S-protein to ACE-2 receptor ${ }^{63-}$ 66. $\mathrm{S}_{\mathrm{N} 501 \mathrm{Y}}$ (Spike protein of SARS-CoV-2 with N501Y mutation) binds to ACE-2 receptor with 7fold higher affinity than the WT whereas $S_{K 417 N}$ (Spike protein of SARS-CoV-2 with K417N mutation) binds with 4 -fold lower affinity ${ }^{67}$. This reflects the possibility of alteration in the binding affinity of the LCB3 inhibitors against the mutated S-protein and needs further investigation. Two common mutations, N501Y and $\mathrm{K} 417 \mathrm{~N}$ are present at the binding interface of the protein (Figure 1) were tested. We have investigated the effect of these two mutations on the binding affinity between LCB3 and S-protein and how to improve the binding affinity by modifying the inhibitors. N501Y mutation is found in various lineages including B.1.1.7 (alpha), B.1.351 (beta), and P.1 (gamma) variants first detected in the U.K., South Africa and Brazil respectively ${ }^{68}$. K417N mutation is present in (beta) lineage B.1.351 and B.1.617.2 (delta plus- a sub-lineage of delta variant $)^{69}$. Both of these mutations (N510Y and K417N) were also reported in the newly detected variant of concern, lineage B.1.1.529 (omicron) ${ }^{70}$. These mutations have immune evasion properties $^{71-73}$.

To investigate the potential change in the binding affinity, associated with the mutations N501Y and K417N of S-protein with LCB3 and to improve the LCB3 inhibitor to make it effective against WT as well as mutants, we have used binding free energy calculation with the well-known Molecular Mechanics Poisson-Boltzmann Surface Area (MM-PBSA) method. We have decomposed the results of the binding affinity per residue of the inhibitor to see which residues 
contribute most to the binding. Then residues of LCB3 that are responsible for less binding affinity are changed to other residues based on the type of interaction and binding site geometry. This simple procedure increases the binding affinity of modified LCB3 with the two mutant forms of the proteins. This procedure is general and can be used to optimize other inhibitors against other mutations as well.

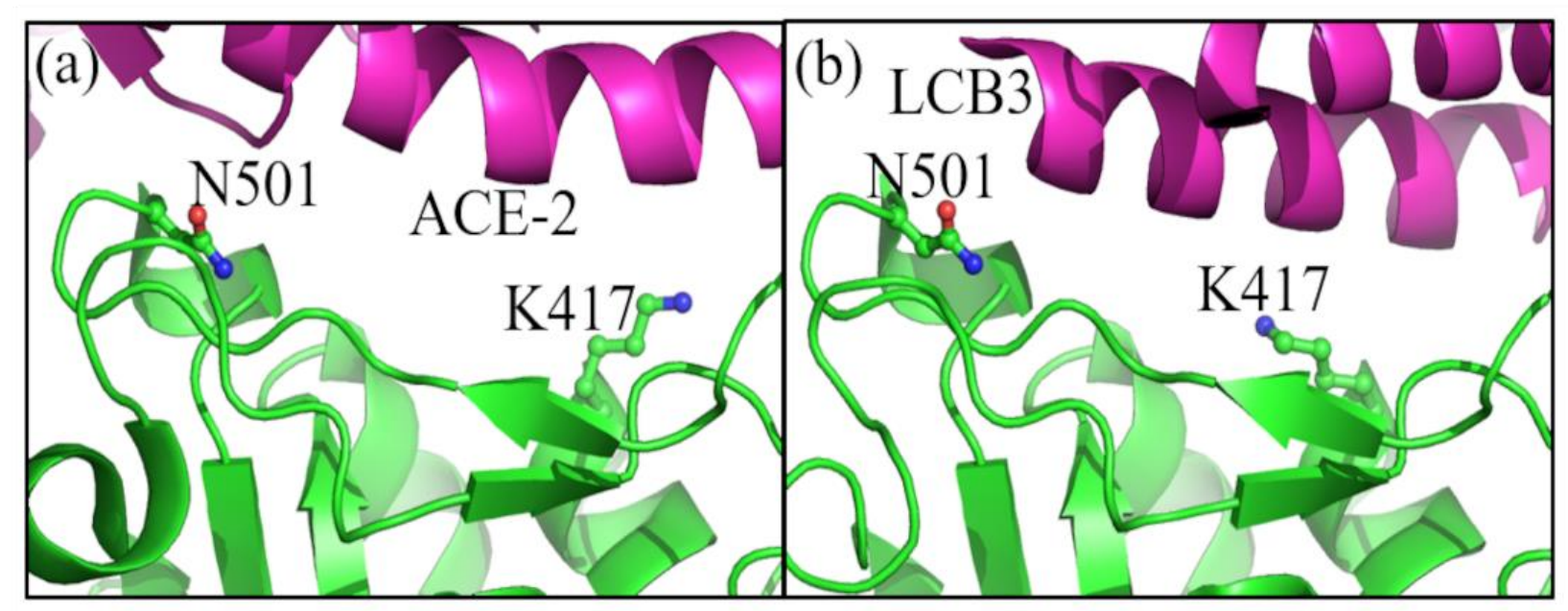

Figure 1: Binding Interface of spike protein (green) with (a) ACE-2 receptor (magenta) using PDB ID: 6M0J and (b) LCB3 miniprotein inhibitor (magenta) using PDB ID: 7JZM. K417 and N501 are shown in the stick.

\section{Materials and Methods:}

2.1 Structure Preparation: The coordinates of S-protein of SARS-CoV-2 with LCB3 inhibitor were retrieved from the protein data bank (PDB) with ID: 7JZM ${ }^{12}$. This structure is used to model the N501Y and K417N mutant of the S-protein and variants of LCB3.

2.2 MD Simulation: ff14SB force field of AMBER 16 package was used to generate the parameters of the proteins ${ }^{74-75}$. All systems were solvated using TIP3P water molecules in a rectangular box using a minimum $10 \AA$ distance between the edges of the box to the surface of the 
$\operatorname{protein}^{76-77}$. Special care was taken to preserve the disulfide bonds present between the cysteine residues present in PDB. Four pairs of Cysteines $\left(\mathrm{C}_{336}-\mathrm{C}_{361}, \mathrm{C}_{379}-\mathrm{C}_{432}, \mathrm{C}_{480}-\mathrm{C}_{488}, \mathrm{C}_{391}-\mathrm{C}_{525}\right)$ of the S protein were involved in the disulfide bonding. Counter ions were added to neutralize the system and to maintain the $0.15 \mathrm{M} \mathrm{KCl}$ salt concentration. 10000 steps of steepest descent followed by 10000 conjugant gradient minimization was used to remove the bad contacts in the solvated system ${ }^{78-79}$. The systems were heated slowly up to $298 \mathrm{~K}$ for $50 \mathrm{ps}$ followed by 50 ps density equilibration with the restraint weight of $2 \mathrm{kcal} / \mathrm{mol} / \AA^{2}$ followed by and 500 ps equilibration run. After equilibration 10 independent simulations of all the complex, each of $10 \mathrm{~ns}$ was performed at NPT (by maintaining $300 \mathrm{~K}$ temperature and 1 atmospheric pressure) to increase the sampling space (Table S1). For entropy calculations, separate long simulations $(1 \mu \mathrm{s})$ of complex, receptor and ligands were performed (Table S2). Hydrogen bonds were constrained using a shake algorithm with 2 fs time integration ${ }^{80}$. The temperature was regulated by Langevin Dynamics with 2 ps of relaxation time ${ }^{81} .1$ bar pressure was controlled by Berendesen's barostat and periodic boundary conditions were applied for all the systems ${ }^{82}$. The particle mesh Ewald summation method was used for the calculation of the long-range electrostatic ${ }^{83}$. CPPTRAJ was used for further analysis of the trajectories obtained from simulation ${ }^{84}$.

2.3 Binding free Energy: MM-PBSA method was used to calculate the binding free energy of WT and mutants of S-protein with LCB3 and its variants. The single trajectory protocol for MMPBSA was performed where the simulation with only the complex was performed, and from that simulation, properties of complex, receptor, and ligand are extracted. In this method, the standard free energy of binding $(\Delta \mathrm{G})$ can be defined by equation 1 which is implemented the in MMPBSA.py script of AMBER16 ${ }^{85}$.

$$
\Delta G_{\text {binding }}=<\Delta G_{\text {complex }}>-<\Delta G_{\text {receptor }}>-<\Delta G_{\text {ligand }}>
$$


Here, $\Delta \mathrm{G}_{\text {complex, }} \Delta \mathrm{G}_{\text {receptor }}, \Delta \mathrm{G}_{\text {ligand }}$ are the free energy of solvation for complex receptor, and ligand respectively. $<>$ denotes the ensemble average.

$\Delta \mathrm{G}_{\text {binding }}$ is calculated by equation 2 :

$\Delta G_{\text {binding }}=\Delta G_{\text {gas }}+\Delta G_{\text {solv }}$

$\Delta \mathrm{G}_{\mathrm{gas}}$ is the change in the gaseous state. It is calculated by equation 5.

$\Delta G_{g a s}=\Delta E_{M M}-T \Delta S$

$\Delta \mathrm{E}_{\mathrm{MM}}$ includes electrostatic (ele) and van der Waals (vdW) components. Another component $\mathrm{T} \Delta \mathrm{S}$ represents the entropic contribution where $\mathrm{T}$ represents the temperature in Kelvin and $\mathrm{S}$ is the solute entropy.

$\Delta \mathrm{G}_{\text {solv }}$ of equation 2 constitutes the polar and nonpolar components, (equation 4).

$\Delta G_{\text {solv }}=\Delta G_{\text {polar }}+\Delta G_{\text {nonpolar }}$

$\Delta \mathrm{G}_{\text {polar }}\left(\Delta \mathrm{G}_{\mathrm{PB}}\right)$ is obtained from the solution of the Poisson Boltzmann equation. $\Delta \mathrm{G}_{\text {nonpolar }}\left(\Delta \mathrm{G}_{\mathrm{np}}\right)$ constitutes of cavitation and dispersion terms (equation 5), where cavitation energy is estimated using a linear relation to the surface of the molecule and the dispersion is calculated using solutesolvent interactions ${ }^{86}$.

$\Delta G_{\text {nonpolar }}=\Delta G_{\text {cavitation }}+\Delta G_{\text {dispersion }}$

The nonpolar component is calculated using equation 6 .

$\Delta G_{\text {nonpolar }}=\gamma S A S A+\beta+\Delta G_{\text {dispersion }}$ 
The value of $\gamma$ and $\beta$ is $0.0378 \mathrm{kcal} / \mathrm{mol}-\AA^{2}$ and $-0.569 \mathrm{kcal} / \mathrm{mol}$ respectively as implemented in the AMBER package. The solvent-accessible surface area (SASA) is used to distinguish the exposed and buried area of the protein. For that, a probe sphere with vdW radii of $\sim 1.4 \AA$ is rolled along the surface and if the probe can cross the area it is considered as surface accessible else the region is considered as buried where the solvent cannot enter.

The $0.15 \mathrm{M}$ ionic concentration was used for MM-PBSA calculations. The dielectric constant of the solute is highly dependent on the characteristics of the investigated system ${ }^{87-88}$. In this study, various dielectric constants of solute were tested and the selection was done based on the similarity with the available data (details given in supporting information, Table S3). The dielectric constant of solute was kept 8 . The total binding energy was averaged using 1000 frames obtained from 10 independent trajectories, each of $10 \mathrm{~ns}$, for all the systems.

The entropy of the complex, receptor and ligand were estimated using Quasi Harmonic (QH) approximation method using CPPTRAJ. A sufficient phase space sampling is required for the reliable estimation of entropic contributions ${ }^{89}$. For that, an overall $11 \mu$ s simulation was performed (Table S2). To estimate the effects of mutation on the flexibility of the system, entropy change (T $\Delta \mathrm{S}$ ) was calculated using 5 lakhs frames from the separate $1 \mu$ s simulation, of complex, receptor and ligand.

\section{Results and Discussions:}

\subsection{Binding Energy Difference between WT and Mutant of S-protein with LCB3 inhibitor:}

The binding free energies of $\mathrm{S}_{\mathrm{WT}}$ (wild-type $\mathrm{S}$-protein), $\mathrm{S}_{\mathrm{N} 501 \mathrm{Y}}$ (asparagine at 501 position of $\mathrm{S}$ protein mutated with tyrosine) and $\mathrm{S}_{\mathrm{K} 417 \mathrm{~N}}$ (lysine at 417 position of S-protein mutated with asparagine) with LCB3 were determined using the MM-PBSA calculations and the values were 
compared. The binding affinity of $S_{\mathrm{K} 417 \mathrm{~N}}$ and $\mathrm{S}_{\mathrm{N} 501 \mathrm{Y}}$ mutants were reduced as compared with $\mathrm{S}_{\mathrm{WT}}$ by $\sim+8 \mathrm{kcal} / \mathrm{mol}$ (Table 1$)$.

The loss of $+7.1 \mathrm{kcal} / \mathrm{mol}$ binding affinity of N501Y mutant of spike protein from WT to the mutant with LCB3 is reported by Williams et al. reflecting the correctness of our calculation protocol. ${ }^{90}$ The $\mathrm{S}_{\mathrm{N} 501 \mathrm{Y}}$ mutation results in a loss of binding due to nonpolar solvation interaction $(+6.44 \mathrm{kcal} / \mathrm{mol})$. There is also a loss of $+2.95 \mathrm{kcal} / \mathrm{mol}$ in polar contributions accompanied by the gain in the van der Waals (vdW) component by $-1.23 \mathrm{kcal} / \mathrm{mol}$ (Table 1$)$.

Table 1: The Binding free energy components of $S_{\mathrm{WT}}, S_{\mathrm{N} 501 \mathrm{Y}}$ and $\mathrm{S}_{\mathrm{K} 417 \mathrm{~N}}$, mutants of $\mathrm{S}$-protein of SARS-CoV-2 with LCB3. The energy values are in $\mathrm{kcal} / \mathrm{mol}$. The calculations were averaged over 1000 frames obtained from 10 independent trajectories, each of $10 \mathrm{~ns}$. The standard error is given in the parenthesis.

\begin{tabular}{lllllll}
\hline System & $\boldsymbol{\Delta} \mathbf{E}_{\text {ele }}$ & $\Delta \mathbf{E}_{\mathbf{v d W}}$ & $\Delta \mathbf{G}_{\mathbf{n p}}$ & $\Delta \mathbf{G}_{\mathbf{P B}}$ & $\Delta \mathbf{G}_{\text {ele }} \mathbf{P B}$ & $\Delta \mathbf{G}_{\text {Total }}$ \\
\hline $\mathrm{S}_{\mathrm{WT}}$ & $-62.21(0.4)$ & $44.98(0.7)$ & $-66.42(0.4)$ & $59.80(0.3)$ & $-2.41(0.4)$ & $-23.85(0.6)$ \\
$\mathrm{S}_{\mathrm{N} 501 \mathrm{Y}}$ & $-49.77(0.6)$ & $43.75(1.0)$ & $-59.98(0.6)$ & $50.31(0.5)$ & $0.54(0.6)$ & $-15.69(0.6)$ \\
$\mathrm{S}_{\mathrm{K} 417 \mathrm{~N}}$ & $-33.01(0.5)$ & $42.18(0.9)$ & $-61.41(0.5)$ & $36.61(0.5)$ & $3.60(0.5)$ & $-15.63(0.6)$ \\
\hline $\mathrm{S}_{\mathrm{N} 501 \mathrm{Y}}-\mathrm{S}_{\mathrm{WT}}$ & +12.44 & -1.23 & +6.44 & -9.49 & +2.95 & +8.16 \\
\hline $\mathrm{S}_{\mathrm{K} 417 \mathrm{~N}}-\mathrm{S}_{\mathrm{WT}}$ & +29.2 & -2.80 & +5.01 & -23.19 & +6.01 & +8.22 \\
\hline
\end{tabular}

The lower binding affinity of $S_{\mathrm{K} 417 \mathrm{~N}}$ mutant is mainly due to the loss in polar interactions $(+6.01$ $\mathrm{kcal} / \mathrm{mol})$ and non-polar solvation $(\sim+5.01 \mathrm{kcal} / \mathrm{mol})$ with the slight gain of $-2.80 \mathrm{kcal} / \mathrm{mol}$ of vdW interactions. It reflects that when the positively charged residue lysine was mutated with the uncharged polar asparagine residue, the polar interactions reduced. 
3.2 Residue-Wise Free Energy Decomposition: The reduced binding affinity of LCB3 with $\mathrm{S}_{\mathrm{K} 417 \mathrm{~N}}$ and $\mathrm{S}_{\mathrm{N} 501 \mathrm{Y}}$ mutants provided the scope to improve the LCB3 inhibitor further in such a way so that it can work potently and inhibit the WT as well as mutants. For that, residue-wise free energy decomposition was performed for the identification of important residues ${ }^{91}$. Free energy contributions of each residue were decomposed into electrostatic, vdW, and polar solvation and the amino residues of LCB3 near the mutated residue of S-protein were analyzed (Table 2). D3 (aspartic acid at 3rd position) and E4 (glutamic acid at 4th position) of LCB3 are present near N501 (asparagine at position 501) of S-protein whereas T10 (threonine at 10th position) and D11 (aspartic acid at 11th position) of LCB3 present in the vicinity of K417 (lysine at 417 position) (Figure 2). There is the loss of $+1.0 \mathrm{kcal} / \mathrm{mol}$ and $+0.5 \mathrm{kcal} / \mathrm{mol}$ in the $\mathrm{vdW}$ component of D3 of LCB3 with $S_{N 501 Y}$ and $S_{K 417 N}$ respectively. These losses were compensated with the gain in the polar contributions, and the contribution of D3 was almost similar in $\mathrm{S}_{\mathrm{N} 501 \mathrm{Y}}$ whereas slightly lesser $(+0.3 \mathrm{kcal} / \mathrm{mol})$ in $\mathrm{S}_{\mathrm{K} 417 \mathrm{~N}}$ (Table 2$)$. However, the mutation $\left(\mathrm{S}_{\mathrm{N} 501 \mathrm{Y}}\right.$ or $\left.\mathrm{S}_{\mathrm{K} 417 \mathrm{~N}}\right)$ leads to the overall loss of $\sim+8 \mathrm{kcal} / \mathrm{mol}$ (Table 1$)$. The loss in the energy contributions of $\mathrm{E} 4\left(+1.3 \mathrm{kcal} / \mathrm{mol}\right.$ in $\mathrm{S}_{\mathrm{N} 501 \mathrm{Y}}$ and $+0.5 \mathrm{kcal} / \mathrm{mol}$ in $\left.\mathrm{S}_{\mathrm{K} 417 \mathrm{~N}}\right)$, T10 (+0.2 kcal/mol in $\mathrm{S}_{\mathrm{N} 501 \mathrm{Y}}$ and $+0.7 \mathrm{kcal} / \mathrm{mol}$ in $\left.\mathrm{S}_{\mathrm{K} 417 \mathrm{~N}}\right)$ and D11 $\left(+0.9 \mathrm{kcal} / \mathrm{mol}\right.$ in $\mathrm{S}_{\mathrm{N} 501 \mathrm{Y}}$ and $+0.5 \mathrm{kcal} / \mathrm{mol}$ in $\left.\mathrm{S}_{\mathrm{K} 417 \mathrm{~N}}\right)$ were observed in both $\mathrm{S}_{\mathrm{N} 501 \mathrm{Y}}$ and $\mathrm{S}_{\mathrm{K} 417 \mathrm{~N}}$ (Table 2). It is likely that the interactions between these residues of LCB3 and neighboring residues of the S-protein have the maximum contribution to the loss in binding affinity. 
Table 2: Free energy contributions of important residues of LCB3 present in the vicinity of N501 and K417, averaged over 1000 frames from the simulation of 10 independent trajectories each of 10 ns. Calculations were performed from the single trajectory method using the simulation of LCB3 complexed with wild-type and mutants of S-protein of SARS-CoV-2. All values are in $\mathrm{kcal} / \mathrm{mol}$.

\begin{tabular}{lllllll}
\hline Residue of & System & $\Delta \mathrm{E}_{\mathrm{ele}}$ & $\Delta \mathrm{E}_{\mathrm{vdW}}$ & $\Delta \mathrm{G}_{\mathrm{PB}}$ & $\Delta \mathrm{G}_{\mathrm{PB}+\text { elec }}$ & $\Delta \mathrm{G}_{\text {Total }}$ \\
$\mathrm{LCB3}$ & & & & & &
\end{tabular}

\begin{tabular}{ccccccc}
\hline & $\mathrm{S}_{\mathrm{WT}}$ & -6.1 & -2.7 & 7.9 & +1.8 & -0.9 \\
& $\mathrm{~S}_{\mathrm{N} 501 \mathrm{Y}}$ & -3.7 & -1.7 & 4.4 & +0.7 & -1.0 \\
& $\mathrm{~S}_{\mathrm{K} 417 \mathrm{~N}}$ & -3.7 & -2.2 & 5.3 & +1.6 & -0.6 \\
\hline \multirow{2}{*}{$\mathrm{E} 4$} & $\mathrm{~S}_{\mathrm{WT}}$ & -4.9 & -3.9 & 5.5 & +0.6 & -3.3 \\
& $\mathrm{~S}_{\mathrm{N} 501 \mathrm{Y}}$ & -3.9 & -2.3 & 4.2 & +0.3 & -2.0 \\
& $\mathrm{~S}_{\mathrm{K} 417 \mathrm{~N}}$ & -2.8 & -3.5 & 3.5 & +0.7 & -2.8 \\
\hline \multirow{2}{*}{$\mathrm{T} 10$} & $\mathrm{~S}_{\mathrm{WT}}$ & -0.6 & -2.5 & 0.4 & -0.2 & -2.7 \\
& $\mathrm{~S}_{\mathrm{N} 501 \mathrm{Y}}$ & -0.4 & -2.6 & 0.5 & +0.1 & -2.5 \\
& $\mathrm{~S}_{\mathrm{K} 417 \mathrm{~N}}$ & -0.1 & -2.2 & 0.3 & +0.2 & -2.0 \\
& & & & & \\
\hline $\mathrm{D} 11$ & $\mathrm{~S}_{\mathrm{WT}}$ & -10.3 & 0.4 & 9.8 & -0.5 & -0.1 \\
& $\mathrm{~S}_{\mathrm{N} 501 \mathrm{Y}}$ & -7.5 & 0.7 & 7.6 & +0.1 & 0.8
\end{tabular}




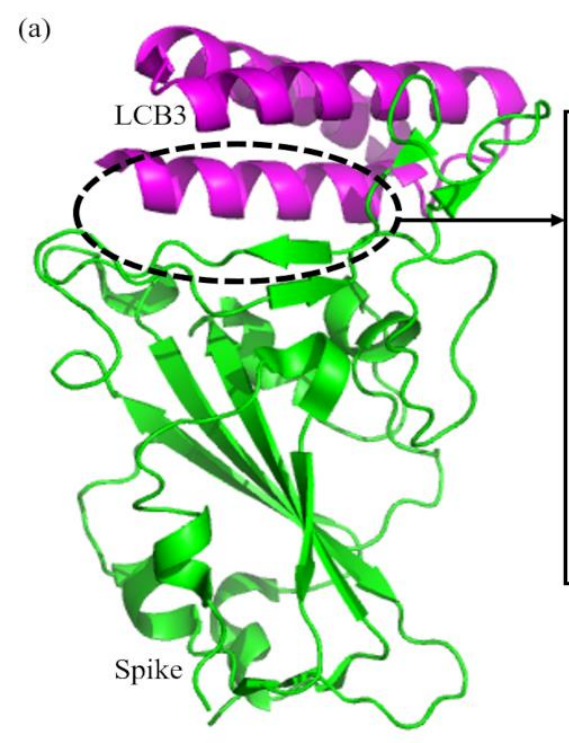

(b)

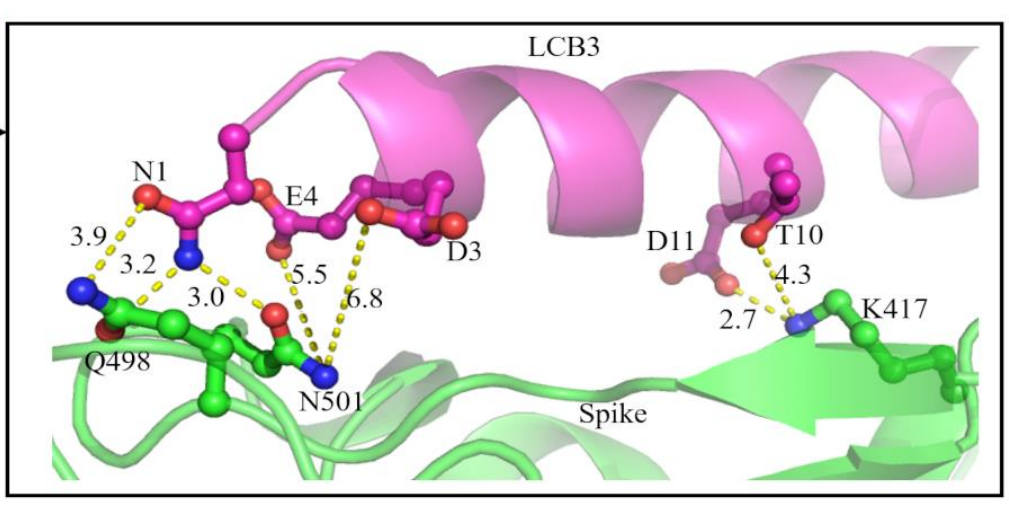

Figure 2: (a) Representative snapshot obtained after $10 \mathrm{~ns}$ simulation of PDB ID: 7JZM. (b) Detailed view of the binding interface: the interacting residues are shown in the stick representation. The distance among the oppositely charged atoms which may interact is given in A.

3.3 Mutation Induced Conformational Changes in the Binding pattern of LCB3: Apart from the free energy contributions, it is also essential to understand the mutations induced conformational changes and interaction patterns to improve the binding affinity. In $\mathrm{S}_{\mathrm{WT}}$ the N1, D3, and E4 of LCB3 form polar interaction with Q498 and N501 of S-protein (Figure 2 and 3a). The replacement of polar asparagine by hydrophobic tyrosine (N501Y) disrupts the electrostatic contribution (Figure 3b) of asparagine which was reflected in Table 1. In the structure of S-protein with ACE2 receptor, the polar residues are surrounded by two tyrosine residues Y41 of ACE2 and Y505 of S-protein (Figure 3c) ${ }^{92}$ which was lacking with LCB3 inhibitor. 


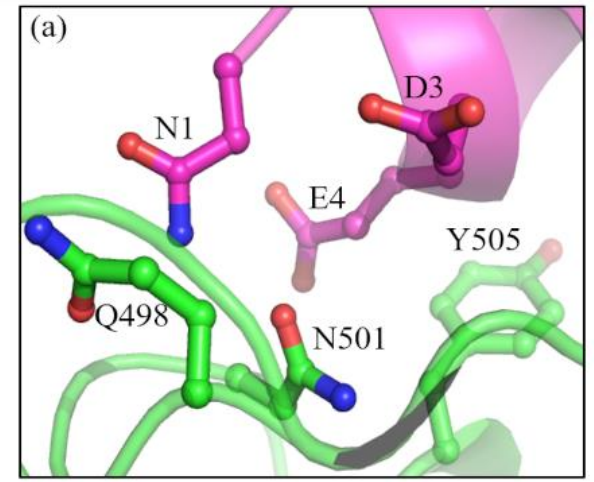

$\mathrm{S}_{\mathrm{WI}}-\mathrm{LCB} 3$

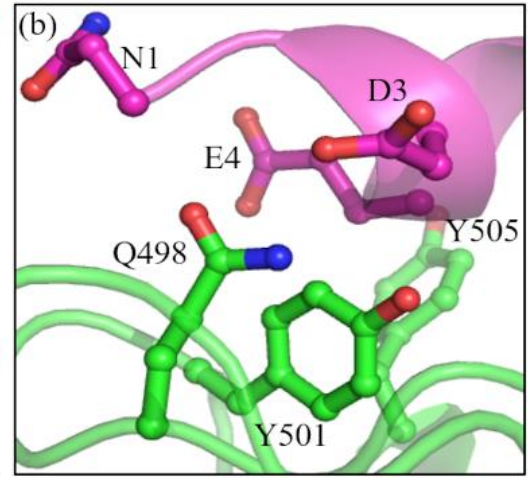

$\mathrm{S}_{\mathrm{N} 501 \mathrm{Y}}-\mathrm{LCB} 3$

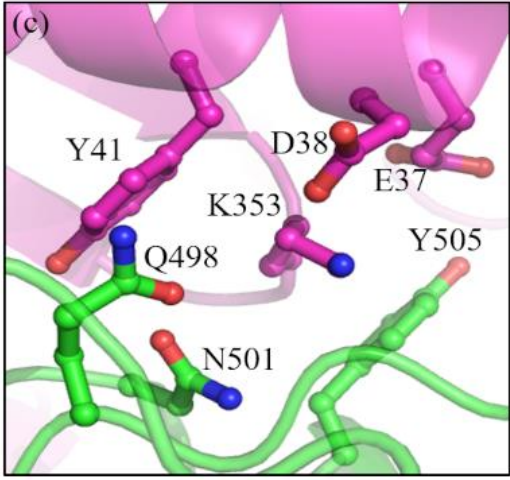

$\mathrm{S}_{\mathrm{WT}} \mathrm{ACE} 2$

Figure 3: Interaction pattern in the binding interface of S-protein around N501 and the mutant Y501 (a) $\mathrm{S}_{\mathrm{WT}}$ with LCB3 after 10 ns simulation of PDB ID:7JZM (b) $\mathrm{S}_{\mathrm{N} 501 \mathrm{Y}}$ with LCB3 after 10 ns simulation and (c) SwT with ACE2; coordinates taken from PDB ID: 6M0J.

In $S_{\mathrm{K} 417 \mathrm{~N}}$, the replacement of a long side-chain residue lysine with asparagine weakens the interaction between $\mathrm{S}_{\mathrm{K} 417 \mathrm{~N}}$ and LCB3 inhibitor (Figure 2, 4a, and 4b). This conformational change leads to the overall loss of $+8.22 \mathrm{kcal} / \mathrm{mol}$ in the binding affinity of $\mathrm{S}_{\mathrm{K} 417 \mathrm{~N}}$ with LCB3 inhibitor (Table 1).
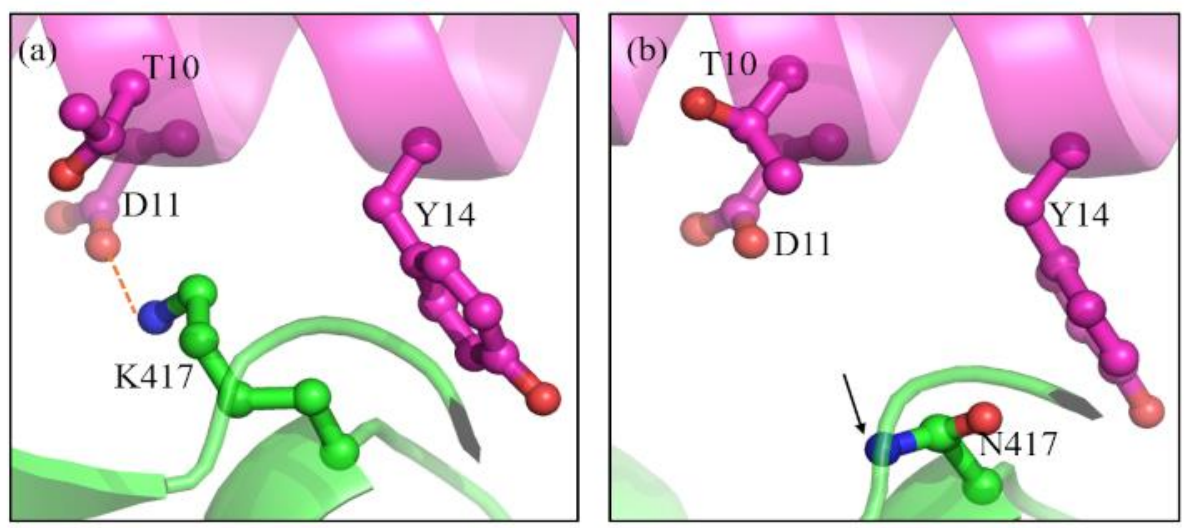

Figure 4: Representative snapshot obtained after 10 ns simulation of (a) SwT-LCB3: K417 of S-

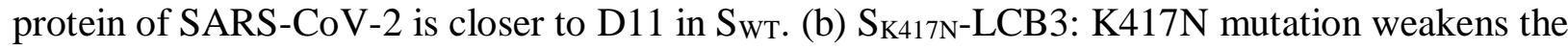
binding affinity of LCB3 with $\mathrm{S}_{\mathrm{K} 417 \mathrm{~N}}$. 


\subsection{Substitution in LCB3 inhibitor for the improvement of the binding affinity with the}

mutants of S-protein Based on the free energy and geometric analysis described in the previous section, we aimed to improve the interaction of Y501 and N417 of $\mathrm{S}_{\mathrm{N} 501 \mathrm{Y}}$ and $\mathrm{S}_{\mathrm{K} 417 \mathrm{~N}}$ respectively with LCB3 by doing minimal change in LCB3. For this, the residues of LCB3 around Y501 of $\mathrm{S}_{\mathrm{N} 501 \mathrm{Y}}$ and $\mathrm{K} 417$ of $\mathrm{S}_{\mathrm{K} 417 \mathrm{~N}}$ were targeted.

D3 and E4 of LCB3 were selected for modifications in $\mathrm{S}_{\mathrm{N} 501 \mathrm{Y}}$. There is a maximum of 19 possible mutations at each position, instead of testing them all here, we first tested the change of D3 by F and $\mathrm{Y}$ with the probability of forming pi-pi interactions or hydrophobic clusters with Y501 and Y505 (Figure 5a). Further, it may also help in improving the vdW contribution of Y3 of LCB3 which was lost by $+1.0 \mathrm{kcal} / \mathrm{mol}$ in $\mathrm{S}_{\mathrm{N} 501 \mathrm{Y}}$ as compared to the $\mathrm{S}_{\mathrm{WT}}$ (Table 2). MM-PBSA

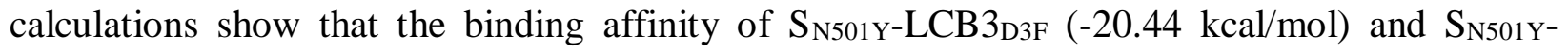
LCB3 $_{\mathrm{D} 3 \mathrm{Y}}(-23.68 \mathrm{kcal} / \mathrm{mol})$ has improved as compared to the $\mathrm{S}_{\mathrm{N} 501 \mathrm{Y}} \mathrm{LCB} 3(-15.69 \mathrm{kcal} / \mathrm{mol})$. The improvement was due to the contribution of non-polar solvation energy (Table 1, 3). The effect of substitution of glutamic acid by tyrosine at the $4^{\text {th }}$ position of LCB3 was tested. The binding affinity of $\mathrm{S}_{\mathrm{N} 501 \mathrm{Y}}-\mathrm{LCB} 3_{\mathrm{E} 4 \mathrm{Y}}$ was $-18.25 \mathrm{kcal} / \mathrm{mol}$, higher than the $\mathrm{S}_{\mathrm{N} 501 \mathrm{Y}}-\mathrm{LCB} 3$ but lower than the

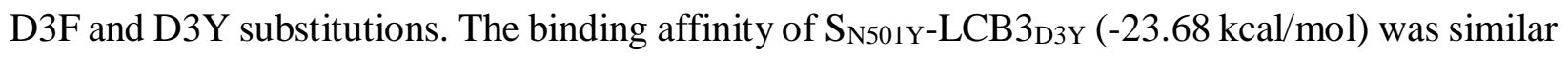
to the $\mathrm{S}_{\mathrm{WT}} \mathrm{LCB} 3(-23.85 \mathrm{kcal} / \mathrm{mol})$ therefore this modification can be successfully used against $\mathrm{S}_{\mathrm{N} 501 \mathrm{Y}}$. Further, we checked the binding affinity of LCB3D3Y with $\mathrm{S}_{\mathrm{WT}}$. Interestingly, we found that $\mathrm{LCB}_{\mathrm{D} 3 \mathrm{Y}}$ has a higher affinity with $\mathrm{S}_{\mathrm{WT}},-28.17 \mathrm{kcal} / \mathrm{mol}$ as compared to the LCB3 -23.85 $\mathrm{kcal} / \mathrm{mol}$ (Table 1,3$)$. The increase in the affinity was due to the gain in $\mathrm{vdW}$ by $-4.23 \mathrm{kcal} / \mathrm{mol}$ and polar contributions by $-1.05 \mathrm{kcal} / \mathrm{mol}$ accompanied by loss of $\sim+1 \mathrm{kcal} / \mathrm{mol}$ in nonpolar components (Table 1, 3; Figure 5b). 
Table 3: Binding free energy components of LCB3 variants with mutants and wild-type spike protein. Calculations averaged over 1000 frames obtained from 10 independent trajectories, each of $10 \mathrm{~ns}$. The standard error is given in the parenthesis. Energy values are in $\mathrm{kcal} / \mathrm{mol}$.

\begin{tabular}{|c|c|c|c|c|c|c|c|}
\hline System & $\Delta \mathbf{E}_{\text {ele }}$ & $\Delta \mathbf{E}_{\mathrm{vdW}}$ & $\Delta \mathbf{G}_{\mathrm{np}}$ & $\Delta \mathbf{G}_{\mathrm{PB}}$ & $\Delta \mathbf{G}_{\text {ele }+ \text { PB }}$ & $\Delta \mathbf{G}_{\text {Total }}$ & $\Delta \Delta G_{\text {Bind }}{ }^{* *}$ \\
\hline$S_{\text {N501Y }}-$ LCB3 ${ }_{\text {D3F }}$ & $-51.66(0.2)$ & $46.02(0.3)$ & $-64.77(0.2)$ & 49.97(0.1) & $-1.69(0.2)$ & $-20.44(0.2)$ & +3.41 \\
\hline $\mathrm{S}_{\mathrm{N} 501 \mathrm{Y}}-\mathrm{LCB} 3{ }_{\mathrm{D} 3 \mathrm{Y}}$ & $-46.11(0.2)$ & $43.35(0.4)$ & $-65.75(0.3)$ & $44.83(0.3)$ & $-1.28(0.3)$ & $-23.68(0.3)$ & +0.17 \\
\hline$S_{\text {K417N }}-$ LCB3 & $-21.17(0.5)$ & $38.17(0.6)$ & $-62.72(0.3)$ & $25.29(0.4)$ & $4.12(0.4)$ & $-20.43(0.2)$ & +3.42 \\
\hline $\mathrm{S}_{\mathrm{WT}}-\mathrm{LCB} 3{ }_{\mathrm{D} 3 \mathrm{Y}}$ & $-54.13(0.4)$ & $40.75(0.7)$ & $-65.46(0.4)$ & $50.67(0.3)$ & $-3.46(0.4)$ & $-28.17(0.7)$ & -4.32 \\
\hline$S_{\mathrm{N} 501 \mathrm{Y}}-\mathrm{LCB} 3_{\mathrm{E} 4 \mathrm{Y}}$ & $-48.72(0.6)$ & 45.92(0.9) & $-63.38(0.5)$ & 47.93(0.5) & $-0.79(0.5)$ & $-18.25(0.6)$ & +5.60 \\
\hline$S_{\mathrm{K} 417 \mathrm{~N}}-\mathrm{LCB} 3_{\mathrm{T} 10 \mathrm{D}}$ & $-39.39(0.5)$ & $47.22(0.5)$ & $-67.46(0.4)$ & $54.65(0.5)$ & $15.26(0.5)$ & $-4.98(0.7)$ & +18.87 \\
\hline $\mathrm{S}_{\mathrm{K} 417 \mathrm{~N}}-\mathrm{LCB} 3_{\mathrm{T} 10 \mathrm{E}}$ & $-34.56(0.5)$ & 42.01(0.7) & $-63.66(0.4)$ & $41.03(0.4)$ & $6.47(0.5)$ & $-15.18(0.6)$ & +8.67 \\
\hline$S_{\mathrm{K} 417 \mathrm{~N}}-\mathrm{LCB} 3_{\mathrm{T} 10 \mathrm{Q}}$ & $-28.28(0.5)$ & $41.13(0.8)$ & $-60.05(0.5)$ & $31.60(0.4)$ & $3.32(0.5)$ & $-15.60(0.6)$ & +8.25 \\
\hline$S_{K 417 N}-L C B 3_{D 11 R}$ & $-20.73(0.4)$ & $40.38(0.7)$ & $-63.41(0.4)$ & $26.41(0.4)$ & $5.68(0.4)$ & $-17.35(0.5)$ & +6.50 \\
\hline$S_{K 417 N}-L C B 3_{D 11 H}$ & $-23.61(0.4)$ & $39.87(0.6)$ & $-67.43(0.4)$ & $27.79(0.4)$ & $4.18(0.4)$ & $-23.38(0.5)$ & +0.47 \\
\hline $\mathrm{S}_{\mathrm{K} 417 \mathrm{~N}}-\mathrm{LCB} 3{ }_{\mathrm{D} 11 \mathrm{HID}}$ & $-23.06(0.4)$ & $40.2(0.7)$ & $-63.42(0.5)$ & $27.89(0.4)$ & $4.83(0.4)$ & $-18.39(0.5)$ & +5.46 \\
\hline $\mathrm{S}_{\mathrm{N} 501 \mathrm{Y}}-\mathrm{LCB} 3_{\mathrm{D} 11 \mathrm{H}}$ & $-36.06(0.1)$ & $43.63(0.3)$ & $-60.52(0.2)$ & $39.01(0.1)$ & $2.95(0.1)$ & $-13.94(0.2)$ & +9.91 \\
\hline $\mathrm{S}_{\mathrm{wT}}-\mathrm{LCB} 3_{\mathrm{D} 11 \mathrm{H}}$ & $-42.90(0.1)$ & $41.17(0.2)$ & $-66.38(0.1)$ & $45.78(0.1)$ & $2.88(0.1)$ & $-22.33(0.2)$ & +1.52 \\
\hline
\end{tabular}

$\Delta \Delta \mathrm{G}_{\mathrm{Bind}}{ }^{* *}=\Delta \mathrm{G}_{\mathrm{System}}-\Delta \mathrm{G}_{\mathrm{s}(\mathrm{WT})}$. Here, 'S(WT)' refers to the wild-type spike protein and the 'system' refers to the first column of this table. 


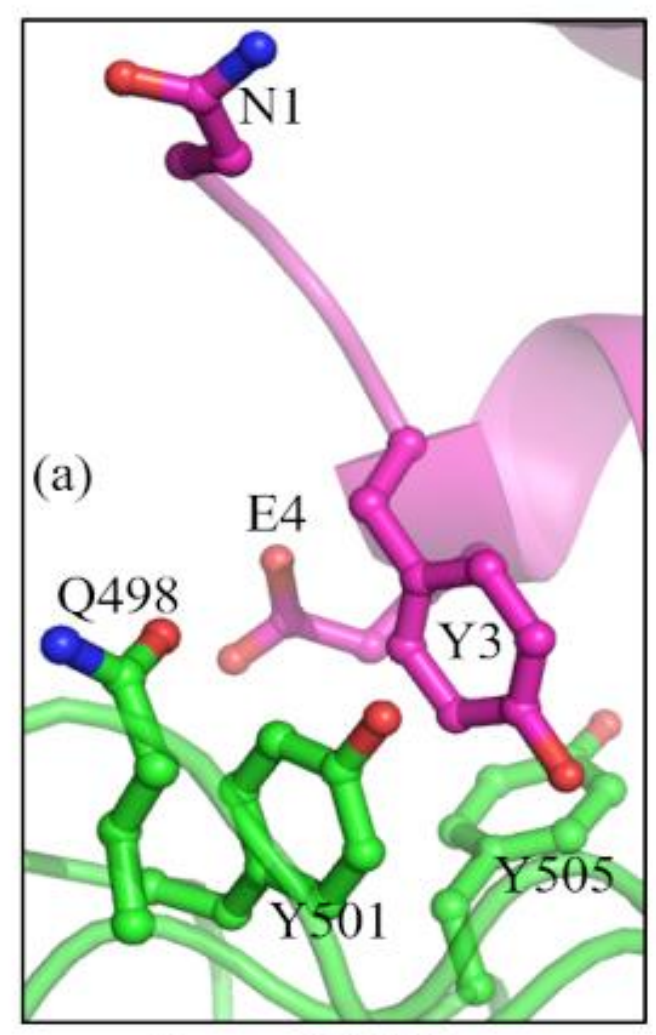

$\mathrm{S}_{\mathrm{N} 501 \mathrm{Y}}-\mathrm{LCB} 3_{\mathrm{D} 3 \mathrm{Y}}$

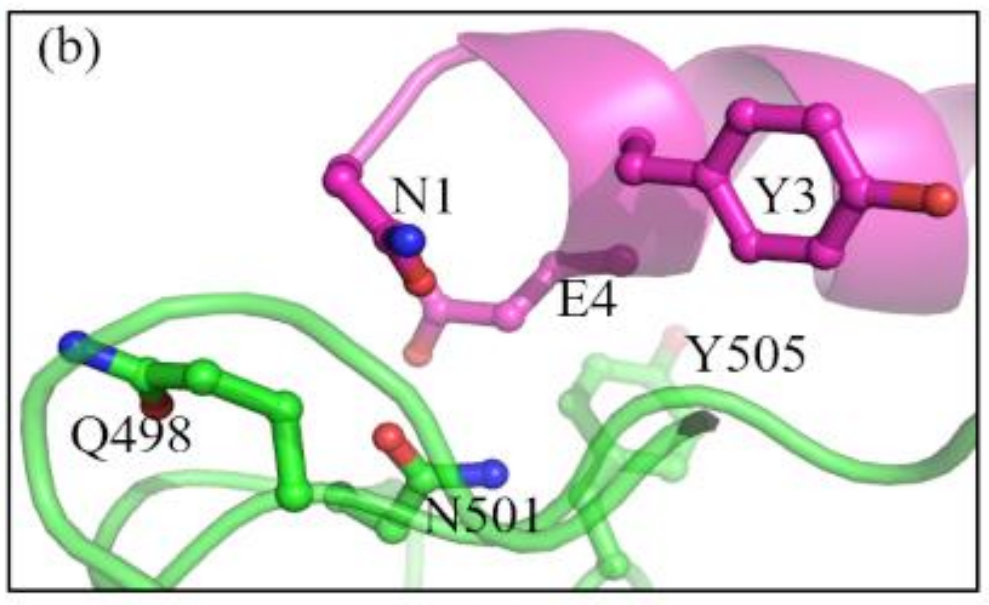

$\mathrm{S}_{\mathrm{WI}}-\mathrm{LCB} 3_{\mathrm{D} 3 \mathrm{Y}}$

Figure 5: Representative conformation obtained after simulation of $L C B 3_{\mathrm{D} 3 \mathrm{Y}}$ with (a) $\mathrm{S}_{\mathrm{N} 501 \mathrm{Y}}$ (b)

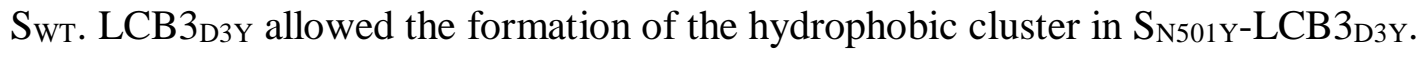

To overcome the loss in the binding affinity of $S_{K 417 N}$, two residues of LCB3: T10, and D11 were targeted for substitutions, based on the loss in the free energy contributions of the residues, and the distance from the mutated K417 (Table 2, Figure 2 and 4). Substitutions of the amino acid T10 of LCB3 by D, E and Q were tested with the possibility to improve polar interaction with N417 but none of these have enhanced the affinity (Table 3). D11 is closer to K417 than T10 (Figure 2), forms direct polar interaction with $\mathrm{K} 417$ (Figure $2 \mathrm{~b}$ ), and there is a loss of $+0.5 \mathrm{kcal} / \mathrm{mol}$ in the free energy contributions of D11 in $S_{\mathrm{K} 417 \mathrm{~N}}$ as compared to $\mathrm{S}_{\mathrm{WT}}$ (Table 2). Therefore, D11 was replaced with a bulky and long side-chain amino acid that can interact with N417. In this regard, two substitutions, D11R and D11H were tested. The binding affinity of the LCB3 D11R with K417N 
is $-17.35 \mathrm{kcal} / \mathrm{mol}, \sim+6.5 \mathrm{kcal} / \mathrm{mol}$ lesser affinity than the $\mathrm{S}_{\mathrm{WT}}-\mathrm{LCB} 3$ (Table 3). However, LCB3 ${ }_{\text {D11H }}$ showed a higher binding affinity $(-23.38 \mathrm{kcal} / \mathrm{mol})$ with $\mathrm{S}_{\mathrm{K} 417 \mathrm{~N}}$ (Table 3$)$. Here, two different protonation states of histidine, at ND1 (HID) and HE2 (HIE) were tested. Histidine with protonation at HE2 (HIE) has shown higher binding affinity as compared to HID. 'H' refers to the 'HIE' protonation state in this paper. From the structure, it was found that the imidazole ring moves towards the binding interface and comes closer to N417 (Figure 6 a), and strengthens the binding by improving the nonpolar solvation component (Table 2). The binding affinity of LCB3 $11 \mathrm{H}$ with $\mathrm{S}_{\mathrm{WT}}$ is $-22.33 \mathrm{kcal} / \mathrm{mol}$, slightly less than the binding affinity of LCB3. In $\mathrm{S}_{\mathrm{WT}}-\mathrm{LCB} 3_{\mathrm{D} 11 \mathrm{H}}, \mathrm{K} 417$ of S-protein repels the H11 slightly away from the binding interface (Figure 6b).
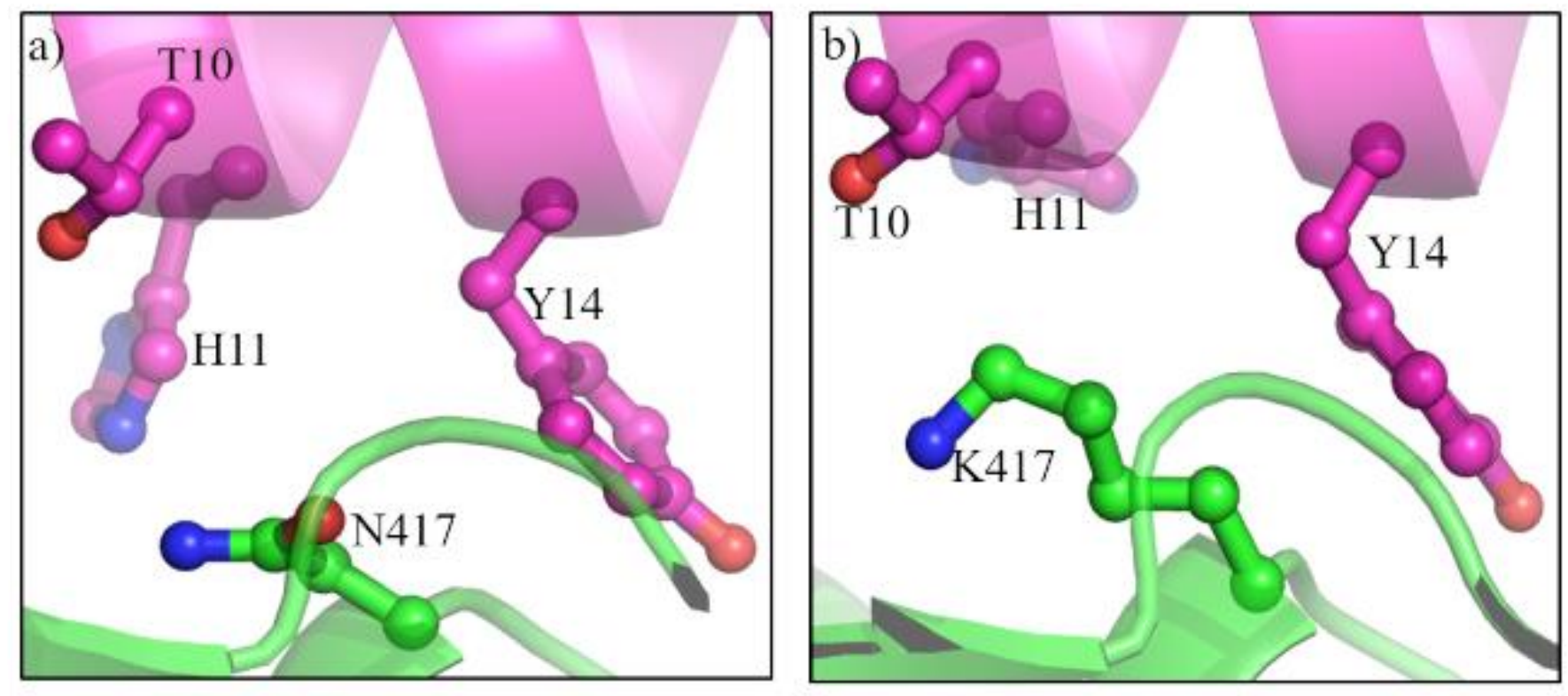

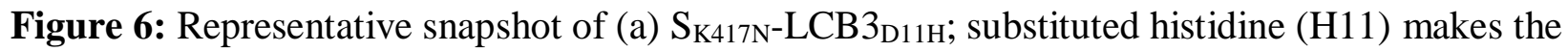
interaction more compact with $\mathrm{S}_{\mathrm{K} 417 \mathrm{~N}}$ as compared to the LCB3 in Figure $4 \mathrm{~b}$. (b) $\mathrm{S}_{\mathrm{WT}} \mathrm{LCB}$ - $\mathrm{D} 11 \mathrm{H}$; the long side chain of K417 pushed H11 away from the binding interface.

Further, the binding affinity of $\mathrm{S}_{\mathrm{K} 417 \mathrm{~N}}$ with $\mathrm{LCB} 3_{\mathrm{D} 3 \mathrm{Y}}$ was tested, which has already shown good affinity with $S_{\mathrm{WT}}$ and $\mathrm{S}_{\mathrm{N} 501 \mathrm{Y}}$. The binding affinity of $\mathrm{S}_{\mathrm{K} 417 \mathrm{~N}-\mathrm{LCB} 3 \mathrm{D} 3 \mathrm{Y}}$ was found $-20.43 \mathrm{kcal} / \mathrm{mol}$. 
It showed that the LCB3 $33 \mathrm{Y}$ can bind efficiently with the $\mathrm{S}_{\mathrm{WT}}(-28.17), \mathrm{S}_{\mathrm{N} 501 \mathrm{Y}}(-23.68 \mathrm{kcal} / \mathrm{mol})$, and also with $\mathrm{S}_{\mathrm{K} 417 \mathrm{~N}}(-20.43 \mathrm{kcal} / \mathrm{mol})$ when compared to the original LCB3 inhibitor. Further, $\mathrm{S}_{\mathrm{K} 417 \mathrm{~N}}$ has a stronger binding affinity with $\mathrm{LCB}_{\mathrm{D} 11 \mathrm{H}}(-23.38 \mathrm{kcal} / \mathrm{mol})$ as compared to the LCB3 $_{\mathrm{D} 3 \mathrm{Y}}(-20.43 \mathrm{kcal} / \mathrm{mol})$. However, LCB3 ${ }_{\mathrm{D} 11 \mathrm{H}}$ does not bind efficiently with $\mathrm{S}_{\mathrm{N} 501 \mathrm{Y}}(-13.95$ $\mathrm{kcal} / \mathrm{mol})$.

In the binding free energy calculations described so far, the entropy of solute is not considered, a common practice in MM-PBSA calculations. However, for the present problem, the calculation of solute entropy is important as changes in amino acids in either S-protein or LCB3 can change the flexibility of the system leading to a change in entropy. As the entropy calculations are computationally intensive, we have performed it for some important systems as mentioned in Table 4 . The change in the entropy was calculated over separate $1 \mu$ s trajectories complex, receptor and ligand. The entropy essentially converges for each system in $1 \mu \mathrm{s}$ MD simulation (Figure 7a to c). The negative of the change in entropy multiplied by temperature, $\mathrm{T}$ (the last term of equation (3), $-\mathrm{T} \Delta \mathrm{S})$ of LCB3 $(+55.5 \mathrm{kcal} / \mathrm{mol})$ and its two variants $\mathrm{LCB} 3_{\mathrm{D} 3 \mathrm{Y}}(+56.0 \mathrm{kcal} / \mathrm{mol})$ and LCB3 $_{\mathrm{D} 11 \mathrm{H}}(+56.2 \mathrm{kcal} / \mathrm{mol})$ with $\mathrm{S}_{\mathrm{WT}}$ were almost similar with no significant differences between them (Figure 7d, Table S4). However, the significant differences in $-\mathrm{T} \Delta \mathrm{S}$ were observed for $\mathrm{S}_{\mathrm{N} 501 \mathrm{Y}-\mathrm{LCB} 3 \mathrm{D} 3 \mathrm{Y}}(+49.4 \mathrm{kcal} / \mathrm{mol})$ and $\mathrm{S}_{\mathrm{K} 417 \mathrm{~N}-\mathrm{LCB} 3 \mathrm{D} 11 \mathrm{H}}(+24.4 \mathrm{kcal} / \mathrm{mol})$. In both these cases, the entropy change on binding was significantly reduced. This reduction in the change of entropy will also help in improving the binding affinity of these variants of LCB3 with mutated S-protein (equation 3). It reflects that the binding affinity of $\mathrm{S}_{\mathrm{WT}}$ with the proposed variants of LCB3 is mainly enthalpy driven; however, in the mutated $\mathrm{S}$-protein $\left(\mathrm{S}_{\mathrm{N} 501 \mathrm{Y}}\right.$ and $\left.\mathrm{S}_{\mathrm{K} 417 \mathrm{~N}}\right)$ entropic changes played significant contributions in improving the binding affinity (Table 4). 

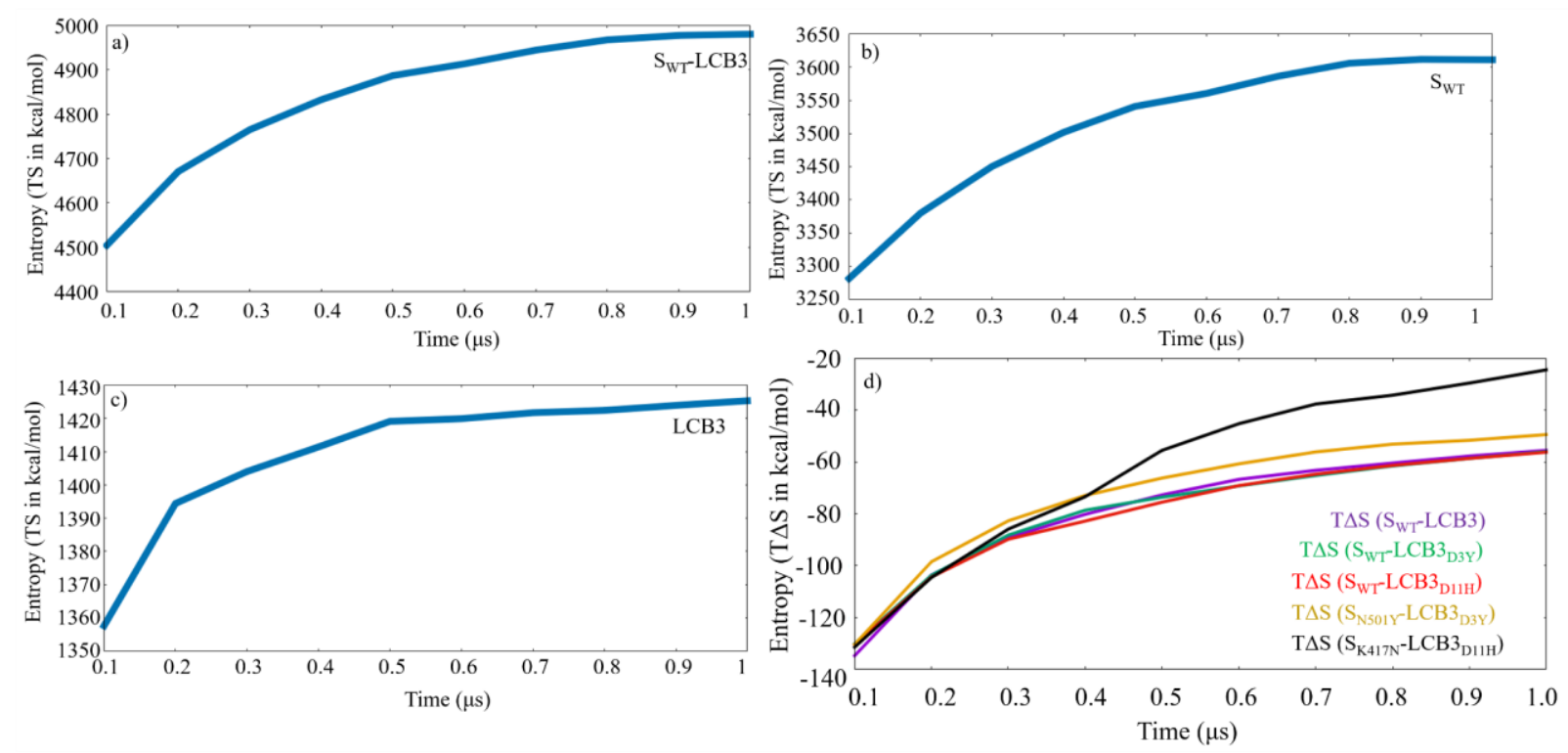

Figure 7: Convergence plot of (a) TS over $1 \mu$ s simulation of $\mathrm{S}_{\mathrm{WT}}-\mathrm{LCB} 3$ (b) $\mathrm{S}_{\mathrm{WT}}$ (c) LCB3 (d) $\mathrm{T} \Delta \mathrm{S}$ of $\mathrm{LCB} 3$ and its proposed variant $\mathrm{LCB} 3_{\mathrm{D} 3 \mathrm{Y}}$ and $\mathrm{LCB} 3_{\mathrm{D} 11 \mathrm{H}}$ with $\mathrm{S}_{\mathrm{WT}}, \mathrm{S}_{\mathrm{N} 501 \mathrm{Y}}$ and $\mathrm{S}_{\mathrm{K} 417 \mathrm{~N}}$ over $1 \mu$ s simulation.

Table 4: Entropy Change over $1 \mu$ s simulation of the LCB3 and its successful variants with the wild-type and mutated S-protein. The values of negative change in entropy multiplied by $\mathrm{T}(-\mathrm{T} \Delta \mathrm{S})$ is in $\mathrm{kcal} / \mathrm{mol}$.

\begin{tabular}{lc}
\hline System & Entropy $(-\mathrm{T} \Delta \mathrm{S})$ over 1 $\mu$ s simulation \\
\hline $\mathrm{S}_{\mathrm{WT}}-\mathrm{LCB} 3$ & +55.5 \\
$\mathrm{~S}_{\mathrm{N} 501 \mathrm{Y}}-\mathrm{LCB} 3_{\mathrm{D} 3 \mathrm{Y}}$ & +49.4 \\
$\mathrm{~S}_{\mathrm{K} 417 \mathrm{~N}}-\mathrm{LCB} 3_{\mathrm{D} 1 \mathrm{H}}$ & +24.4 \\
$\mathrm{~S}_{\mathrm{WT}}-\mathrm{LCB} 3_{\mathrm{D} 3 \mathrm{Y}}$ & +56.0 \\
$\mathrm{~S}_{\mathrm{WT}}-\mathrm{LCB} 3_{\mathrm{D} 11 \mathrm{H}}$ & +56.2
\end{tabular}


To summarize, our calculation and analysis show that a judicious combination of free energy decomposition and geometric consideration can suggest ways to improve the inhibitor against specific mutations. Detailed binding affinity calculation that includes solute entropy shows that even a single amino acid change in LCB3 can make it a potent inhibitor to the S-protein and its mutants. In particular, $\mathrm{LCB}_{\mathrm{D} 3 \mathrm{Y}}$ and $\mathrm{LCB} 3_{\mathrm{D} 11 \mathrm{H}}$ were proposed as the variants of $\mathrm{LCB} 3$ that may inhibit the WT as well as mutants of S-protein. It is to be noted that LCB3 is taken as a prototype for more complex systems such as antibodies. Moreover, this methodology is general so that it can be applied to any inhibitor against different targets.

Our calculation methodology does have some caveats. First, as we wanted to develop a fast methodology, only the receptor-binding domain of the S-protein and the LCB inhibitor were considered. The ACE-2 protein is not considered in the calculation. Our choice of using a simpler system is similar to the work done by Williams et al ${ }^{90}$.

\section{Conclusions:}

The fight against SARS-CoV-2 requires further development of vaccines and medicines. One of the main targets to develop a drug against this virus is the spike protein of the virus. Although there are promising drug candidates against the virus, the major issue is how to design/modify inhibitors against the various mutant strains of the virus. In this work, as a proofof-principle study, we have considered a mini-protein inhibitor, LCB3 that binds to the spike protein of SARS-CoV-2. We have devised a computational protocol to modify LCB3 against the two most common mutations in the spike protein, namely, N501Y and K417N. Our computational methodology includes a free energy decomposition procedure in conjunction with a detailed analysis of the binding site. Our proposed modified LCB3 is shown to bind to the two mutant forms of the spike protein potently. The binding enthalpy showed that the single residue mutations 
LCB3 $33 \mathrm{Y}$ work well against $\mathrm{S}_{\mathrm{WT}}$ as well as $\mathrm{S}_{\mathrm{N} 501 \mathrm{Y}}$ and $\mathrm{S}_{\mathrm{K} 417 \mathrm{~N}}$. Another modification LCB3D11H binds efficiently with $\mathrm{S}_{\mathrm{K} 417 \mathrm{~N}}$ and $\mathrm{S}_{\mathrm{WT}}$ but not with $\mathrm{S}_{\mathrm{N} 501 \mathrm{Y}}$. Further, the entropic contributions also favor the binding of $\mathrm{LCB}_{\mathrm{D} 3 \mathrm{Y}}$ with $\mathrm{S}_{\mathrm{N} 501 \mathrm{Y}}$, and $\mathrm{LCB} 3{ }_{\mathrm{D} 11 \mathrm{H}}$ with $\mathrm{S}_{\mathrm{K} 417 \mathrm{~N}}$ respectively. The study found that $\mathrm{LCB}_{\mathrm{D} 3 \mathrm{Y}}$ and $\mathrm{LCB} 3 \mathrm{D} 11 \mathrm{H}$ were bound with a higher affinity with the WT as well as mutated Sprotein. This strategy can be useful to redesign the peptide-based inhibitor against the target protein that undergoes frequent mutation.

\section{References:}

1. V'Kovski, P.; Kratzel, A.; Steiner, S.; Stalder, H.; Thiel, V., Coronavirus biology and replication: implications for SARS-CoV-2. Nat Rev Microbiol 2021, 19 (3), 155-170.

2. Hu, B.; Guo, H.; Zhou, P.; Shi, Z. L., Characteristics of SARS-CoV-2 and COVID-19. Nat Rev Microbiol 2021, 19 (3), 141-154.

3. Meyerowitz, E. A.; Richterman, A.; Gandhi, R. T.; Sax, P. E., Transmission of SARSCoV-2: A Review of Viral, Host, and Environmental Factors. Ann Intern Med 2021, 174 (1), 6979.

4. Cao, C.; Cai, Z.; Xiao, X.; Rao, J.; Chen, J.; Hu, N.; Yang, M.; Xing, X.; Wang, Y.; Li, M.; Zhou, B.; Wang, X.; Wang, J.; Xue, Y., The architecture of the SARS-CoV-2 RNA genome inside virion. Nat Commun 2021, 12 (1), 3917.

5. Finkel, Y.; Mizrahi, O.; Nachshon, A.; Weingarten-Gabbay, S.; Morgenstern, D.; Yahalom-Ronen, Y.; Tamir, H.; Achdout, H.; Stein, D.; Israeli, O.; Beth-Din, A.; Melamed, S.; Weiss, S.; Israely, T.; Paran, N.; Schwartz, M.; Stern-Ginossar, N., The coding capacity of SARSCoV-2. Nature 2021, 589 (7840), 125-130.

6. Shamsi, A.; Mohammad, T.; Anwar, S.; Amani, S.; Khan, M. S.; Husain, F. M.; Rehman, M. T.; Islam, A.; Hassan, M. I., Potential drug targets of SARS-CoV-2: From genomics to therapeutics. Int J Biol Macromol 2021, 177, 1-9. 
7. Lee, J.; Lee, J.; Kim, H. J.; Ko, M.; Jee, Y.; Kim, S., TMPRSS2 and RNA-Dependent RNA Polymerase Are Effective Targets of Therapeutic Intervention for Treatment of COVID-19 Caused by SARS-CoV-2 Variants (B.1.1.7 and B.1.351). Microbiol Spectr 2021, 9 (1), e0047221.

8. Alexpandi, R.; De Mesquita, J. F.; Pandian, S. K.; Ravi, A. V., Quinolines-Based SARSCoV-2 3CLpro and RdRp Inhibitors and Spike-RBD-ACE2 Inhibitor for Drug-Repurposing Against COVID-19: An in silico Analysis. Front Microbiol 2020, 11, 1796.

9. El Hassab, M. A.; Shoun, A. A.; Al-Rashood, S. T.; Al-Warhi, T.; Eldehna, W. M., Identification of a New Potential SARS-COV-2 RNA-Dependent RNA Polymerase Inhibitor via Combining Fragment-Based Drug Design, Docking, Molecular Dynamics, and MM-PBSA Calculations. Front Chem 2020, 8, 584894.

10. Xiang, R.; Yu, Z.; Wang, Y.; Wang, L.; Huo, S.; Li, Y.; Liang, R.; Hao, Q.; Ying, T.; Gao, Y.; Yu, F.; Jiang, S., Recent advances in developing small-molecule inhibitors against SARSCoV-2. Acta Pharm Sin B 2021.

11. Pomplun, S.; Jbara, M.; Quartararo, A. J.; Zhang, G.; Brown, J. S.; Lee, Y. C.; Ye, X.; Hanna, S.; Pentelute, B. L., De Novo Discovery of High-Affinity Peptide Binders for the SARSCoV-2 Spike Protein. ACS Cent Sci 2021, 7 (1), 156-163.

12. Cao, L.; Goreshnik, I.; Coventry, B.; Case, J. B.; Miller, L.; Kozodoy, L.; Chen, R. E.; Carter, L.; Walls, A. C.; Park, Y. J.; Strauch, E. M.; Stewart, L.; Diamond, M. S.; Veesler, D.; Baker, D., De novo design of picomolar SARS-CoV-2 miniprotein inhibitors. Science 2020, 370 (6515), 426-431.

13. Yang, C.; Pan, X.; Xu, X.; Cheng, C.; Huang, Y.; Li, L.; Jiang, S.; Xu, W.; Xiao, G.; Liu, S., Salvianolic acid C potently inhibits SARS-CoV-2 infection by blocking the formation of sixhelix bundle core of spike protein. Signal Transduct Target Ther 2020, 5 (1), 220.

14. Vankadari, N., Arbidol: A potential antiviral drug for the treatment of SARS-CoV-2 by blocking trimerization of the spike glycoprotein. Int J Antimicrob Agents 2020, 56 (2), 105998.

15. Wang, X.; Cao, R.; Zhang, H.; Liu, J.; Xu, M.; Hu, H.; Li, Y.; Zhao, L.; Li, W.; Sun, X.; Yang, X.; Shi, Z.; Deng, F.; Hu, Z.; Zhong, W.; Wang, M., The anti-influenza virus drug, arbidol is an efficient inhibitor of SARS-CoV-2 in vitro. Cell Discov 2020, 6, 28.

16. Amani, B.; Amani, B.; Zareei, S.; Zareei, M., Efficacy and safety of arbidol (umifenovir) in patients with COVID-19: A systematic review and meta-analysis. Immun Inflamm Dis 2021, 9 (4), 1197-1208. 
17. Alavi Darazam, I.; Shokouhi, S.; Mardani, M.; Pourhoseingholi, M. A.; Rabiei, M. M.; Hatami, F.; Shabani, M.; Moradi, O.; Gharehbagh, F. J.; Irvani, S. S. N.; Amirdosara, M.; Hajiesmaeili, M.; Rezaei, O.; Khoshkar, A.; Lotfollahi, L.; Gachkar, L.; Dehbsneh, H. S.; Khalili, N.; Soleymaninia, A.; Kusha, A. H.; Shoushtari, M. T.; Torabinavid, P., Umifenovir in hospitalized moderate to severe COVID-19 patients: A randomized clinical trial. Int Immunopharmacol 2021, 99, 107969.

18. Bojadzic, D.; Alcazar, O.; Chen, J.; Chuang, S. T.; Condor Capcha, J. M.; Shehadeh, L. A.; Buchwald, P., Small-Molecule Inhibitors of the Coronavirus Spike: ACE2 Protein-Protein Interaction as Blockers of Viral Attachment and Entry for SARS-CoV-2. ACS Infect Dis 2021, 7 (6), 1519-1534.

19. Chen, C. Z.; Xu, M.; Pradhan, M.; Gorshkov, K.; Petersen, J. D.; Straus, M. R.; Zhu, W.; Shinn, P.; Guo, H.; Shen, M.; Klumpp-Thomas, C.; Michael, S. G.; Zimmerberg, J.; Zheng, W.; Whittaker, G. R., Identifying SARS-CoV-2 Entry Inhibitors through Drug Repurposing Screens of SARS-S and MERS-S Pseudotyped Particles. ACS Pharmacol Transl Sci 2020, 3 (6), 11651175 .

20. Mahoney, M.; Damalanka, V. C.; Tartell, M. A.; Chung, D. H.; Lourenco, A. L.; Pwee, D.; Mayer Bridwell, A. E.; Hoffmann, M.; Voss, J.; Karmakar, P.; Azouz, N. P.; Klingler, A. M.; Rothlauf, P. W.; Thompson, C. E.; Lee, M.; Klampfer, L.; Stallings, C. L.; Rothenberg, M. E.; Pohlmann, S.; Whelan, S. P. J.; O'Donoghue, A. J.; Craik, C. S.; Janetka, J. W., A novel class of TMPRSS2 inhibitors potently block SARS-CoV-2 and MERS-CoV viral entry and protect human epithelial lung cells. Proc Natl Acad Sci U S A 2021, 118 (43).

21. Ko, M.; Jeon, S.; Ryu, W. S.; Kim, S., Comparative analysis of antiviral efficacy of FDAapproved drugs against SARS-CoV-2 in human lung cells. J Med Virol 2021, 93 (3), 1403-1408.

22. Uno, Y., Camostat mesilate therapy for COVID-19. Intern Emerg Med 2020, 15 (8), 1577 1578.

23. Hoffmann, M.; Hofmann-Winkler, H.; Smith, J. C.; Kruger, N.; Arora, P.; Sorensen, L. K.; Sogaard, O. S.; Hasselstrom, J. B.; Winkler, M.; Hempel, T.; Raich, L.; Olsson, S.; Danov, O.; Jonigk, D.; Yamazoe, T.; Yamatsuta, K.; Mizuno, H.; Ludwig, S.; Noe, F.; Kjolby, M.; Braun, A.; Sheltzer, J. M.; Pohlmann, S., Camostat mesylate inhibits SARS-CoV-2 activation by TMPRSS2related proteases and its metabolite GBPA exerts antiviral activity. EBioMedicine 2021, 65, 103255. 
24. Gunst, J. D.; Staerke, N. B.; Pahus, M. H.; Kristensen, L. H.; Bodilsen, J.; Lohse, N.; Dalgaard, L. S.; Bronnum, D.; Frobert, O.; Honge, B.; Johansen, I. S.; Monrad, I.; Erikstrup, C.; Rosendal, R.; Vilstrup, E.; Mariager, T.; Bove, D. G.; Offersen, R.; Shakar, S.; Cajander, S.; Jorgensen, N. P.; Sritharan, S. S.; Breining, P.; Jespersen, S.; Mortensen, K. L.; Jensen, M. L.; Kolte, L.; Frattari, G. S.; Larsen, C. S.; Storgaard, M.; Nielsen, L. P.; Tolstrup, M.; Saedder, E. A.; Ostergaard, L. J.; Ngo, H. T. T.; Jensen, M. H.; Hojen, J. F.; Kjolby, M.; Sogaard, O. S., Efficacy of the TMPRSS2 inhibitor camostat mesilate in patients hospitalized with Covid-19-a double-blind randomized controlled trial. EClinicalMedicine 2021, 35, 100849.

25. Hoffmann, M.; Schroeder, S.; Kleine-Weber, H.; Muller, M. A.; Drosten, C.; Pohlmann, S., Nafamostat Mesylate Blocks Activation of SARS-CoV-2: New Treatment Option for COVID19. Antimicrob Agents Chemother 2020, 64 (6).

26. Zhuravel, S. V.; Khmelnitskiy, O. K.; Burlaka, O. O.; Gritsan, A. I.; Goloshchekin, B. M.; Kim, S.; Hong, K. Y., Nafamostat in hospitalized patients with moderate to severe COVID-19 pneumonia: a randomised Phase II clinical trial. EClinicalMedicine 2021, 41, 101169.

27. Mahmudpour, M.; Nabipour, I.; Keshavarz, M.; Farrokhnia, M., Virtual Screening on Marine Natural Products for Discovering TMPRSS2 Inhibitors. Front Chem 2021, 9, 722633.

28. Mandala, V. S.; McKay, M. J.; Shcherbakov, A. A.; Dregni, A. J.; Kolocouris, A.; Hong, M., Structure and drug binding of the SARS-CoV-2 envelope protein transmembrane domain in lipid bilayers. Nat Struct Mol Biol 2020, 27 (12), 1202-1208.

29. Schoeman, D.; Fielding, B. C., Coronavirus envelope protein: current knowledge. Virol J 2019, $16(1), 69$.

30. Breitinger, U.; Ali, N. K. M.; Sticht, H.; Breitinger, H. G., Inhibition of SARS CoV Envelope Protein by Flavonoids and Classical Viroporin Inhibitors. Front Microbiol 2021, 12, 692423.

31. Mengist, H. M.; Dilnessa, T.; Jin, T., Structural Basis of Potential Inhibitors Targeting SARS-CoV-2 Main Protease. Front Chem 2021, 9, 622898.

32. Ghahremanpour, M. M.; Tirado-Rives, J.; Deshmukh, M.; Ippolito, J. A.; Zhang, C. H.; Cabeza de Vaca, I.; Liosi, M. E.; Anderson, K. S.; Jorgensen, W. L., Identification of 14 Known Drugs as Inhibitors of the Main Protease of SARS-CoV-2. ACS Med Chem Lett 2020, 11 (12), 2526-2533. 
33. Jin, Z.; Du, X.; Xu, Y.; Deng, Y.; Liu, M.; Zhao, Y.; Zhang, B.; Li, X.; Zhang, L.; Peng, C.; Duan, Y.; Yu, J.; Wang, L.; Yang, K.; Liu, F.; Jiang, R.; Yang, X.; You, T.; Liu, X.; Yang, X.; Bai, F.; Liu, H.; Liu, X.; Guddat, L. W.; Xu, W.; Xiao, G.; Qin, C.; Shi, Z.; Jiang, H.; Rao, Z.; Yang, H., Structure of M(pro) from SARS-CoV-2 and discovery of its inhibitors. Nature 2020, 582 (7811), 289-293.

34. Jin, Z.; Wang, H.; Duan, Y.; Yang, H., The main protease and RNA-dependent RNA polymerase are two prime targets for SARS-CoV-2. Biochem Biophys Res Commun 2021, 538, 63-71.

35. Hillen, H. S.; Kokic, G.; Farnung, L.; Dienemann, C.; Tegunov, D.; Cramer, P., Structure of replicating SARS-CoV-2 polymerase. Nature 2020, 584 (7819), 154-156.

36. Kokic, G.; Hillen, H. S.; Tegunov, D.; Dienemann, C.; Seitz, F.; Schmitzova, J.; Farnung, L.; Siewert, A.; Hobartner, C.; Cramer, P., Mechanism of SARS-CoV-2 polymerase stalling by remdesivir. Nat Commun 2021, 12 (1), 279.

37. Naydenova, K.; Muir, K. W.; Wu, L. F.; Zhang, Z.; Coscia, F.; Peet, M. J.; CastroHartmann, P.; Qian, P.; Sader, K.; Dent, K.; Kimanius, D.; Sutherland, J. D.; Lowe, J.; Barford, D.; Russo, C. J., Structure of the SARS-CoV-2 RNA-dependent RNA polymerase in the presence of favipiravir-RTP. Proc Natl Acad Sci U S A 2021, 118 (7).

38. Jiang, Y.; Yin, W.; Xu, H. E., RNA-dependent RNA polymerase: Structure, mechanism, and drug discovery for COVID-19. Biochem Biophys Res Commun 2021, 538, 47-53.

39. Shin, D.; Mukherjee, R.; Grewe, D.; Bojkova, D.; Baek, K.; Bhattacharya, A.; Schulz, L.; Widera, M.; Mehdipour, A. R.; Tascher, G.; Geurink, P. P.; Wilhelm, A.; van der Heden van Noort, G. J.; Ovaa, H.; Muller, S.; Knobeloch, K. P.; Rajalingam, K.; Schulman, B. A.; Cinatl, J.; Hummer, G.; Ciesek, S.; Dikic, I., Papain-like protease regulates SARS-CoV-2 viral spread and innate immunity. Nature 2020, 587 (7835), 657-662.

40. Osipiuk, J.; Azizi, S. A.; Dvorkin, S.; Endres, M.; Jedrzejczak, R.; Jones, K. A.; Kang, S.; Kathayat, R. S.; Kim, Y.; Lisnyak, V. G.; Maki, S. L.; Nicolaescu, V.; Taylor, C. A.; Tesar, C.; Zhang, Y. A.; Zhou, Z.; Randall, G.; Michalska, K.; Snyder, S. A.; Dickinson, B. C.; Joachimiak, A., Structure of papain-like protease from SARS-CoV-2 and its complexes with non-covalent inhibitors. Nat Commun 2021, 12 (1), 743.

41. Fu, Z.; Huang, B.; Tang, J.; Liu, S.; Liu, M.; Ye, Y.; Liu, Z.; Xiong, Y.; Zhu, W.; Cao, D.; Li, J.; Niu, X.; Zhou, H.; Zhao, Y. J.; Zhang, G.; Huang, H., The complex structure of GRL0617 
and SARS-CoV-2 PLpro reveals a hot spot for antiviral drug discovery. Nat Commun 2021, 12 (1), 488 .

42. Moshkovits, I.; Shepshelovich, D., Emergency Use Authorizations of COVID-19-Related Medical Products. JAMA Intern Med 2021.

43. Krause, P. R.; Gruber, M. F., Emergency Use Authorization of Covid Vaccines - Safety and Efficacy Follow-up Considerations. N Engl J Med 2020, 383 (19), e107.

44. Eastman, R. T.; Roth, J. S.; Brimacombe, K. R.; Simeonov, A.; Shen, M.; Patnaik, S.; Hall, M. D., Remdesivir: A Review of Its Discovery and Development Leading to Emergency Use Authorization for Treatment of COVID-19. ACS Cent Sci 2020, 6 (5), 672-683.

45. Razonable, R. R.; Pawlowski, C.; O'Horo, J. C.; Arndt, L. L.; Arndt, R.; Bierle, D. M.; Borgen, M. D.; Hanson, S. N.; Hedin, M. C.; Lenehan, P.; Puranik, A.; Seville, M. T.; Speicher, L. L.; Tulledge-Scheitel, S. M.; Venkatakrishnan, A. J.; Wilker, C. G.; Badley, A. D.; Ganesh, R., Casirivimab-Imdevimab treatment is associated with reduced rates of hospitalization among highrisk patients with mild to moderate coronavirus disease-19. EClinicalMedicine 2021, 40, 101102. 46. Consortium, W. H. O. S. T.; Pan, H.; Peto, R.; Henao-Restrepo, A. M.; Preziosi, M. P.; Sathiyamoorthy, V.; Abdool Karim, Q.; Alejandria, M. M.; Hernandez Garcia, C.; Kieny, M. P.; Malekzadeh, R.; Murthy, S.; Reddy, K. S.; Roses Periago, M.; Abi Hanna, P.; Ader, F.; Al-Bader, A. M.; Alhasawi, A.; Allum, E.; Alotaibi, A.; Alvarez-Moreno, C. A.; Appadoo, S.; Asiri, A.; Aukrust, P.; Barratt-Due, A.; Bellani, S.; Branca, M.; Cappel-Porter, H. B. C.; Cerrato, N.; Chow, T. S.; Como, N.; Eustace, J.; Garcia, P. J.; Godbole, S.; Gotuzzo, E.; Griskevicius, L.; Hamra, R.; Hassan, M.; Hassany, M.; Hutton, D.; Irmansyah, I.; Jancoriene, L.; Kirwan, J.; Kumar, S.; Lennon, P.; Lopardo, G.; Lydon, P.; Magrini, N.; Maguire, T.; Manevska, S.; Manuel, O.; McGinty, S.; Medina, M. T.; Mesa Rubio, M. L.; Miranda-Montoya, M. C.; Nel, J.; Nunes, E. P.; Perola, M.; Portoles, A.; Rasmin, M. R.; Raza, A.; Rees, H.; Reges, P. P. S.; Rogers, C. A.; Salami, K.; Salvadori, M. I.; Sinani, N.; Sterne, J. A. C.; Stevanovikj, M.; Tacconelli, E.; Tikkinen, K. A. O.; Trelle, S.; Zaid, H.; Rottingen, J. A.; Swaminathan, S., Repurposed Antiviral Drugs for Covid19 - Interim WHO Solidarity Trial Results. N Engl J Med 2021, 384 (6), 497-511.

47. Lloyd, E. C.; Gandhi, T. N.; Petty, L. A., Monoclonal Antibodies for COVID-19. JAMA 2021, 325 (10), 1015.

48. Gupta, A.; Gonzalez-Rojas, Y.; Juarez, E.; Crespo Casal, M.; Moya, J.; Falci, D. R.; Sarkis, E.; Solis, J.; Zheng, H.; Scott, N.; Cathcart, A. L.; Hebner, C. M.; Sager, J.; Mogalian, E.; Tipple, 
C.; Peppercorn, A.; Alexander, E.; Pang, P. S.; Free, A.; Brinson, C.; Aldinger, M.; Shapiro, A. E.; Investigators, C.-I., Early Treatment for Covid-19 with SARS-CoV-2 Neutralizing Antibody Sotrovimab. N Engl J Med 2021, 385 (21), 1941-1950.

49. Antonelli, M.; Penfold, R. S.; Merino, J.; Sudre, C. H.; Molteni, E.; Berry, S.; Canas, L. S.; Graham, M. S.; Klaser, K.; Modat, M.; Murray, B.; Kerfoot, E.; Chen, L.; Deng, J.; Osterdahl, M. F.; Cheetham, N. J.; Drew, D. A.; Nguyen, L. H.; Pujol, J. C.; Hu, C.; Selvachandran, S.; Polidori, L.; May, A.; Wolf, J.; Chan, A. T.; Hammers, A.; Duncan, E. L.; Spector, T. D.; Ourselin, S.; Steves, C. J., Risk factors and disease profile of post-vaccination SARS-CoV-2 infection in UK users of the COVID Symptom Study app: a prospective, community-based, nested, case-control study. Lancet Infect Dis 2021.

50. Whitley, R., Molnupiravir - A Step toward Orally Bioavailable Therapies for Covid-19. $N$ Engl J Med 2021.

51. Fischer, W.; Eron, J. J.; Holman, W.; Cohen, M. S.; Fang, L.; Szewczyk, L. J.; Sheahan, T. P.; Baric, R.; Mollan, K. R.; Wolfe, C. R.; Duke, E. R.; Azizad, M. M.; Borroto-Esoda, K.; Wohl, D. A.; Loftis, A. J.; Alabanza, P.; Lipansky, F.; Painter, W. P., Molnupiravir, an Oral Antiviral Treatment for COVID-19. medRxiv 2021.

52. Mahase, E., Covid-19: Pfizer's paxlovid is $89 \%$ effective in patients at risk of serious illness, company reports. BMJ 2021, 375, n2713.

53. Harvey, W. T.; Carabelli, A. M.; Jackson, B.; Gupta, R. K.; Thomson, E. C.; Harrison, E. M.; Ludden, C.; Reeve, R.; Rambaut, A.; Consortium, C.-G. U.; Peacock, S. J.; Robertson, D. L., SARS-CoV-2 variants, spike mutations and immune escape. Nat Rev Microbiol 2021, 19 (7), 409424.

54. Karim, S. S. A.; Karim, Q. A., Omicron SARS-CoV-2 variant: a new chapter in the COVID-19 pandemic. Lancet 2021.

55. McCormick, K. D.; Jacobs, J. L.; Mellors, J. W., The emerging plasticity of SARS-CoV2. Science 2021, 371 (6536), 1306-1308.

56. Domingo, P.; Pomar, V.; Mur, I.; Castellvi, I.; Corominas, H.; de Benito, N., Not all COVID-19 pandemic waves are alike. Clin Microbiol Infect 2021, 27 (7), 1040 e 7-1040 e10.

57. Jia, Z.; Gong, W., Will Mutations in the Spike Protein of SARS-CoV-2 Lead to the Failure of COVID-19 Vaccines? J Korean Med Sci 2021, 36 (18), e124. 
58. Kim, Y. J.; Jang, U. S.; Soh, S. M.; Lee, J. Y.; Lee, H. R., The Impact on Infectivity and Neutralization Efficiency of SARS-CoV-2 Lineage B.1.351 Pseudovirus. Viruses 2021, 13 (4).

59. Chaqroun, A.; Hartard, C.; Schvoerer, E., Anti-SARS-CoV-2 Vaccines and Monoclonal Antibodies Facing Viral Variants. Viruses 2021, 13 (6).

60. Guruprasad, L., Human SARS CoV-2 spike protein mutations. Proteins 2021, 89 (5), 569576.

61. Schrors, B.; Riesgo-Ferreiro, P.; Sorn, P.; Gudimella, R.; Bukur, T.; Rosler, T.; Lower, M.; Sahin, U., Large-scale analysis of SARS-CoV-2 spike-glycoprotein mutants demonstrates the need for continuous screening of virus isolates. PLoS One 2021, 16 (9), e0249254.

62. Khateeb, J.; Li, Y.; Zhang, H., Emerging SARS-CoV-2 variants of concern and potential intervention approaches. Crit Care 2021, 25 (1), 244.

63. Tian, F.; Tong, B.; Sun, L.; Shi, S.; Zheng, B.; Wang, Z.; Dong, X.; Zheng, P., N501Y mutation of spike protein in SARS-CoV-2 strengthens its binding to receptor ACE2. Elife 2021, 10.

64. Khan, A.; Zia, T.; Suleman, M.; Khan, T.; Ali, S. S.; Abbasi, A. A.; Mohammad, A.; Wei, D. Q., Higher infectivity of the SARS-CoV-2 new variants is associated with K417N/T, E484K, and N501Y mutants: An insight from structural data. J Cell Physiol 2021, 236 (10), 7045-7057.

65. Ozono, S.; Zhang, Y.; Ode, H.; Sano, K.; Tan, T. S.; Imai, K.; Miyoshi, K.; Kishigami, S.; Ueno, T.; Iwatani, Y.; Suzuki, T.; Tokunaga, K., SARS-CoV-2 D614G spike mutation increases entry efficiency with enhanced ACE2-binding affinity. Nat Commun 2021, 12 (1), 848.

66. Ali, F.; Kasry, A.; Amin, M., The new SARS-CoV-2 strain shows a stronger binding affinity to ACE2 due to N501Y mutant. Med Drug Discov 2021, 10, 100086.

67. Laffeber, C.; de Koning, K.; Kanaar, R.; Lebbink, J. H. G., Experimental Evidence for Enhanced Receptor Binding by Rapidly Spreading SARS-CoV-2 Variants. J Mol Biol 2021, 433 (15), 167058.

68. Rambaut, A.; Holmes, E. C.; O'Toole, A.; Hill, V.; McCrone, J. T.; Ruis, C.; du Plessis, L.; Pybus, O. G., Addendum: A dynamic nomenclature proposal for SARS-CoV-2 lineages to assist genomic epidemiology. Nat Microbiol 2021, 6 (3), 415.

69. Duong, D., Alpha, Beta, Delta, Gamma: What's important to know about SARS-CoV-2 variants of concern? CMAJ 2021, 193 (27), E1059-E1060. 
70. Zhang, X.; Wu, S.; Wu, B.; Yang, Q.; Chen, A.; Li, Y.; Zhang, Y.; Pan, T.; Zhang, H.; He, X., SARS-CoV-2 Omicron strain exhibits potent capabilities for immune evasion and viral entrance. Signal Transduct Target Ther 2021, 6 (1), 430.

71. Focosi, D.; Maggi, F., Neutralising antibody escape of SARS-CoV-2 spike protein: Risk assessment for antibody-based Covid-19 therapeutics and vaccines. Rev Med Virol 2021, 31 (6), e2231.

72. Fratev, F., N501Y and K417N Mutations in the Spike Protein of SARS-CoV-2 Alter the Interactions with Both hACE2 and Human-Derived Antibody: A Free Energy of Perturbation Retrospective Study. J Chem Inf Model 2021.

73. Hu, J.; Peng, P.; Cao, X.; Wu, K.; Chen, J.; Wang, K.; Tang, N.; Huang, A. L., Increased immune escape of the new SARS-CoV-2 variant of concern Omicron. Cell Mol Immunol 2022.

74. Maier, J. A.; Martinez, C.; Kasavajhala, K.; Wickstrom, L.; Hauser, K. E.; Simmerling, C., ff14SB: Improving the Accuracy of Protein Side Chain and Backbone Parameters from ff99SB. $J$ Chem Theory Comput 2015, 11 (8), 3696-713.

75. D.A. Case, R. M. B., D.S. Cerutti, T.E. Cheatham, III, T.A. Darden, R.E. Duke, T.J. Giese, H. Gohlke,; A.W. Goetz, N. H., S. Izadi, P. Janowski, J. Kaus, A. Kovalenko, T.S. Lee, S. LeGrand, P. Li, C.; Lin, T. L., R. Luo, B. Madej, D. Mermelstein, K.M. Merz, G. Monard, H. Nguyen, H.T. Nguyen, I.; Omelyan, A. O., D.R. Roe, A. Roitberg, C. Sagui, C.L. Simmerling, W.M. Botello-Smith, J. Swails,; R.C. Walker, J. W., R.M. Wolf, X. Wu, L. Xiao and P.A. Kollman, AMBER 2016, University of California, San Francisco. 2016.

76. William L. Jorgensen, J. C., and Jeffry D. Madura, Comparison of simple potential functions for simulating liquid water. The Journal of chemical physics 1983, 79 (2), 926-935.

77. Case, D. A.; Cheatham, T. E., 3rd; Darden, T.; Gohlke, H.; Luo, R.; Merz, K. M., Jr.; Onufriev, A.; Simmerling, C.; Wang, B.; Woods, R. J., The Amber biomolecular simulation programs. J Comput Chem 2005, 26 (16), 1668-88.

78. D.Solov'ev, S. S. P., The Origin of the Method of Steepest Descent. Historia Mathematica 1997, 24 (4), 361-375.

79. Hestenes, M. R., On the iterative methods for solving linear systems of equations. Journal of Optimization Theory and Applications 1973, 11 (4), 323-334.

80. CAndersen, H., Rattle: A “velocity” version of the shake algorithm for molecular dynamics calculations. 1983, $52(1), 24-34$. 
81. Izaguirre, J. A., Langevin stabilization of molecular dynamics. The Journal of Chemical Physics 2001, 114 (5), 2090-2098.

82. H. J. C. Berendsen, J. P. M. P., W. F. van Gunsteren, A. DiNola, and J. R. Haak, Molecular Dynamics with Coupling to an External Bath. J. Chem. Phys 1984, 81 (8), 10089-10092.

83. Tom Darden, D. Y., and Lee Pedersen, An $N \cdot \log (\mathrm{N})$ Method for Ewald Sums in Large Systems. J. Chem. Phys 1993, 98 (12), 10089-10092.

84. Roe, D. R.; Cheatham, T. E., 3rd, PTRAJ and CPPTRAJ: Software for Processing and Analysis of Molecular Dynamics Trajectory Data. J Chem Theory Comput 2013, 9 (7), 3084-95.

85. Miller, B. R., 3rd; McGee, T. D., Jr.; Swails, J. M.; Homeyer, N.; Gohlke, H.; Roitberg, A. E., MMPBSA.py: An Efficient Program for End-State Free Energy Calculations. J Chem Theory Comput 2012, 8 (9), 3314-21.

86. Chunhu Tan, Y.-H. T., and Ray Luo, Implicit Nonpolar Solvent Models. J. Phys. Chem. B 2007, 111 (42), 12263-12274.

87. Wang, E.; Weng, G.; Sun, H.; Du, H.; Zhu, F.; Chen, F.; Wang, Z.; Hou, T., Assessing the performance of the MM/PBSA and MM/GBSA methods. 10. Impacts of enhanced sampling and variable dielectric model on protein-protein Interactions. Phys Chem Chem Phys 2019, 21 (35), 18958-18969.

88. Hou, T.; Wang, J.; Li, Y.; Wang, W., Assessing the performance of the MM/PBSA and MM/GBSA methods. 1. The accuracy of binding free energy calculations based on molecular dynamics simulations. J Chem Inf Model 2011, 51 (1), 69-82.

89. Kushick, M. K. a. J. N., Method for estimating the configurational entropy of macromolecules. Macromolecules 1981, 14 (2), 325-332.

90. Williams, A. H.; Zhan, C. G., Fast Prediction of Binding Affinities of the SARS-CoV-2 Spike Protein Mutant N501Y (UK Variant) with ACE2 and Miniprotein Drug Candidates. J Phys Chem B 2021, 125 (17), 4330-4336.

91. Gohlke, H.; Kiel, C.; Case, D. A., Insights into protein-protein binding by binding free energy calculation and free energy decomposition for the Ras-Raf and Ras-RalGDS complexes. $J$ Mol Biol 2003, 330 (4), 891-913.

92. Lan, J.; Ge, J.; Yu, J.; Shan, S.; Zhou, H.; Fan, S.; Zhang, Q.; Shi, X.; Wang, Q.; Zhang, L.; Wang, X., Structure of the SARS-CoV-2 spike receptor-binding domain bound to the ACE2 receptor. Nature 2020, 581 (7807), 215-220. 
bioRxiv preprint doi: https://doi.org/10.1101/2022.02.27.482153; this version posted February 28, 2022. The copyright holder for this preprint (which was not certified by peer review) is the author/funder, who has granted bioRxiv a license to display the preprint in perpetuity. It is made available under aCC-BY-ND 4.0 International license. 